\title{
Are attitudes determined by location? Differences in perceptions of asylum seekers between residents of two Zagreb neighbourhoods
}

Gregurović, Margareta; Radeljak Kaufmann, Petra; Župarić-Iljić, Drago; Dujmović, Morgane

Source / Izvornik: Geoforum, 2019, 104, 244 - 258

Journal article, Accepted version

Rad u časopisu, Završna verzija rukopisa prihvaćena za objavljivanje (postprint)

https://doi.org/10.1016/j.geoforum.2019.05.004

Permanent link / Trajna poveznica: https://urn.nsk.hr/urn:nbn:hr:131:506755

Rights / Prava: In copyright/Zaštićeno autorskim pravom.

Download date / Datum preuzimanja: 2023-04-26

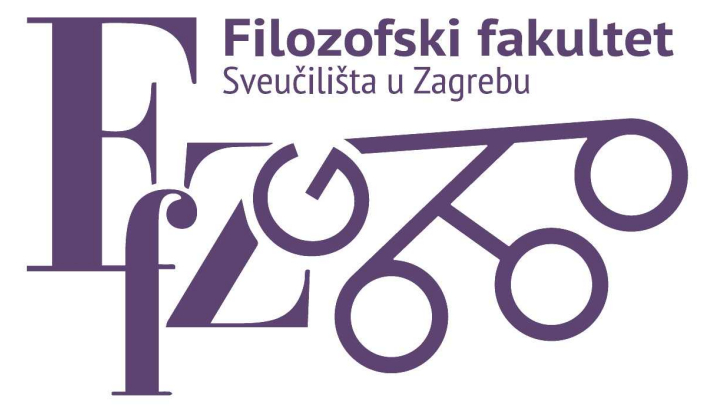

Repository / Repozitorij:

ODRAZ - open repository of the University of Zagreb Faculty of Humanities and Social Sciences
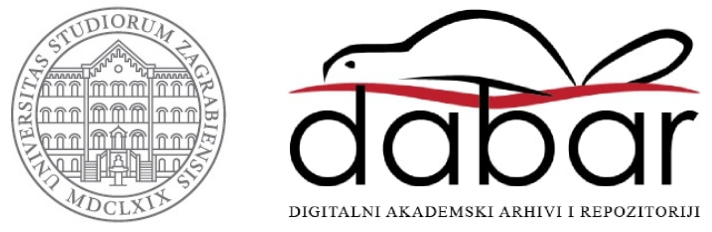


\author{
Margareta Gregurović, Petra Radeljak Kaufmann, Drago Župarić-Iljić, Morgane \\ Dujmović
}

\title{
Are Attitudes Determined by Location? Differences in Perceptions of Asylum Seekers between Residents of Two Zagreb Neighbourhoods
}

\begin{abstract}
Based on two theoretical approaches - contact theory and threat perception theory - in combination with meaningful encounter and media perspective and using the example of two neighbourhoods in Zagreb, this paper aims to explore several issues related to asylum seekers: 1 ) the definition and perceptions of asylum seekers expressed by locals; 2 ) attitudes towards asylum seekers in relation to vicinity to an asylum seeker centre and contact with asylum seekers on the neighbourhood level; and 3 ) the relationship between attitudes and socio-demographic characteristics of respondents. The survey was conducted in the period of November, 2015 to January, 2016, using a systematic random sample $(\mathrm{N}=299)$ in two selected neighbourhoods of the City of Zagreb: Dugave and Trnje. Each neighbourhood represents a specific surrounding in relation to the proximity of asylum seekers. In terms of location and contact with the asylum seekers, significant differences were found in all obtained latent dimensions of attitudes towards asylum seekers and attitudes based on locational attributes regarding asylum seeker reception: Dugave residents (located closer to the reception and accommodation centre) expressed, in general, more negative attitudes towards asylum seekers and their reception in Croatia than their counterparts in Trnje. The specific timeframe (the 2015-2016 sequence usually referred to as "European Migration Crisis") and the spatial context chosen for conducting the survey allows for spatialised and comparative findings. The discussion further develops the perceptive role played by media in a context of highly-mediatised migration, and the nature of contact in shaping more positive or negative attitudes towards refugees and migrants.
\end{abstract}

Key Words: asylum seekers, social contact, threat perception, neighbourhood, media, Zagreb (Croatia)

\section{INTRODUCTION}

Personal knowledge on issues related to asylum seekers, intergroup contacts, socio-demographic characteristics of individuals, and the way asylum seekers are depicted by the media and various other influential actors, are some of the main factors upon which opinions and attitudes towards asylum seekers depend (See: McKay et al., 2012). Besides being described generally as "refugees", they were often perceived negatively as "threatening", "burdensome", "illegal", "other", and "immigrants" (See: Klocker, 2004; Holmes and Castañeda, 2016), which can ultimately affect policies enacted by governments and behaviours towards asylum seekers at the regional and local levels. Objections to asylum seeker centres have typically been related to fears of racial and cultural differences, safety issues, economic burden, devaluation of property, etc. (Klocker, 2004; Hubbard, 2005; Lubbers et al., 
2006). On the other hand, intergroup contact has been credited with lessening prejudice, especially in cases of "right" characteristics of the contact situation (Allport, 1954; Pettigrew and Tropp, 2005; Pettigrew et al., 2011). There are also other positive outcomes of intergroup contact, such as reduced anxiety, individual and collective threat, enhanced empathy, etc. (Pettigrew et al., 2011).

This research emerged from the actuality of asylum seeker issues in 2015 and 2016 in Croatia and the need for a scientific approach in analysing the situation related to mass-arrivals and transit of refugees and other forced migrants through the Balkan Route ${ }^{1}$-and with specific groups of residents of Zagreb, the capital of Croatia, ${ }^{2}$-in order to describe the perceptions of asylum seekers in regard to their (spatial) proximity (to locals). Therefore, this paper aims to explore several issues related to asylum seekers: 1 ) the perception of asylum seekers, i.e. how citizens in the host country (Croatia) define asylum seekers' identities and origins; 2 ) attitudes towards asylum seekers in relation to vicinity to an asylum seeker centre and contact with asylum seekers on the neighbourhood level; and 3) the relationship between those attitudes and respondents' socio-demographic characteristics. The main question raised within the scope of the research relates to the influence of contact with asylum seekers among residents of different neighbourhoods in the same city: are there differences in attitudes between the residents of a neighbourhood where an asylum seeker shelter is located and residents of a neighbourhood that is not in close proximity to the shelter? To ascertain this, a questionnaire survey was conducted, which included residents of Dugave and Trnje neighbourhoods in Zagreb. Dugave is one of the neighbourhoods in New Zagreb (south of the Sava River) which were planned and built predominantly as residential developments in the second half of the $20^{\text {th }}$ century. Hotel Porin, the asylum seeker shelter, is located there, $6.52 \mathrm{~km}$ from Zagreb's city centre ${ }^{3}$ in a direct line. Its location allows for more frequent contact between residents of Dugave and asylum seekers and refugees. Trnje is more centrally-located, encompassing several highly-urbanised neighbourhoods (Figure 1).

\footnotetext{
${ }^{1}$ The "Balkan Route" is the widely-used name for the path(s) used by forced migrants that usually begins in Turkey and then winds through either Bulgaria or Greece. The migrants then make their way further north, eventually reaching Croatia, Slovenia or Hungary on the way towards countries such as Germany.

${ }^{2}$ According to the last, 2011 census, the population of Zagreb's inner urban area was 688,163, while the population of the greater City of Zagreb was 790,017. In the administrative division of Croatia, the City of Zagreb is simultaneously a local and a regional self-government unit (city/county).

${ }^{3}$ The distance between Hotel Porin and the city centre (Ban Jelačić Square) was measured using Google Earth Pro (17/09/2017).
} 


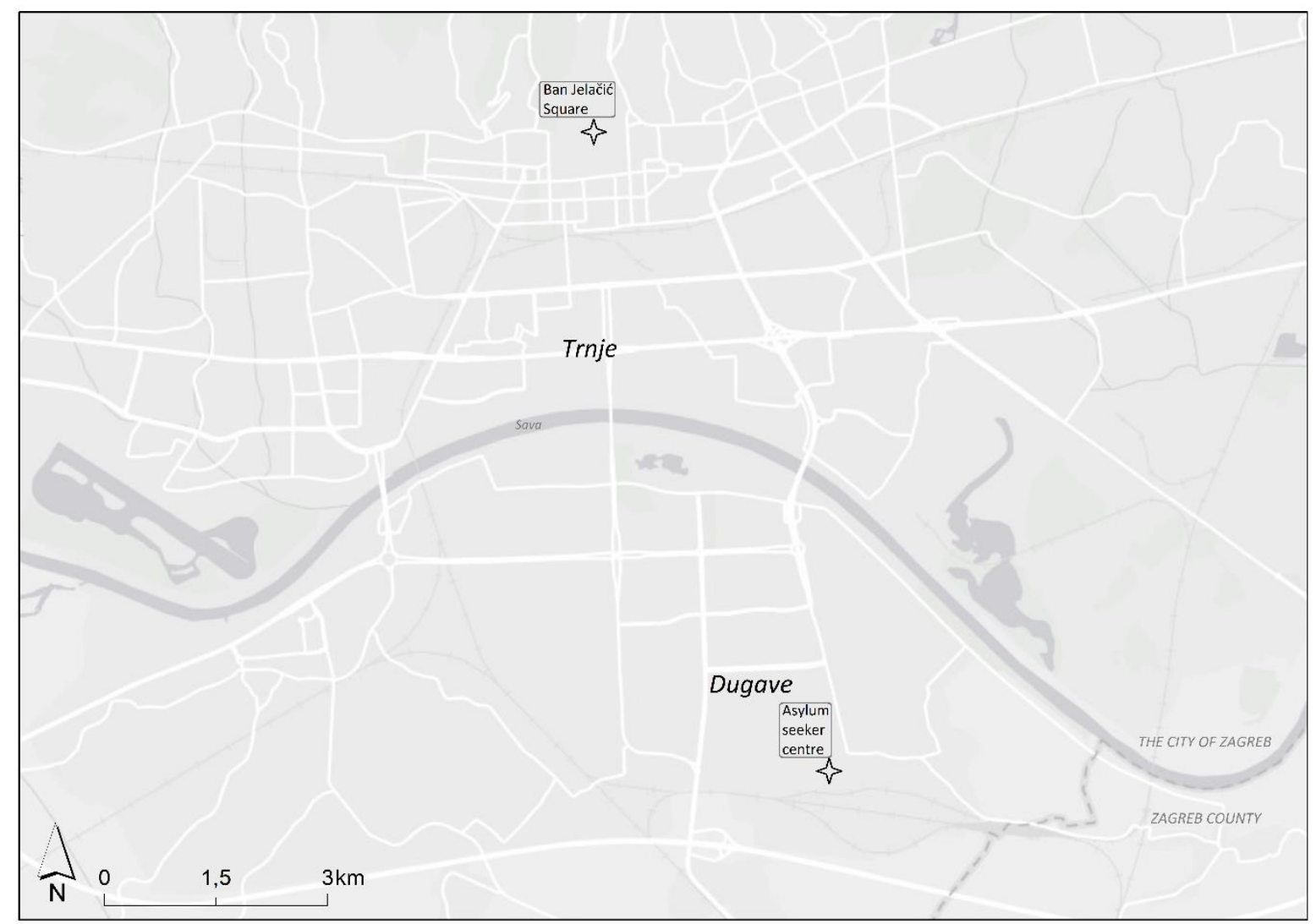

Figure 1. Locations of Dugave and Trnje neighbourhoods in relation to Zagreb's centre (Ban Jelačić Square $)^{4}$

The theoretical framework of this paper is grounded on the plethora of discussions related to asylum seeker issues and general attitudes on immigration in scholarly literature. Apart from considering the way asylum seekers are depicted and the influence of socio-demographic characteristics on attitude formation, we focused special attention on contact theory, as well as theories related to group threat (conflict) hypothesis. Along with confronting the contact and conflict approach, the focus of the research is set on a location/neighbourhood framework. Finally, as stated by van Kempen and Wissink (2014), focusing the research on the residential location alone would be too narrow, given the spatial mobility of people, as well as communication technologies. In relation to this, we also pay special attention to the influence of media. Following the theoretical framework, the general and crosssectional Croatian context is described, providing the relevant information for the understanding the obtained results. The description of the research sample and methodology will be followed by the presentation and discussion of definitions of asylum seekers given by respondents, their first source of information on the subject of asylum, attitudes towards asylum seekers based on the dimensions of social contact, economy/health, ethnocultural similarity, asylum seeker credibility estimation, as well as attitudes based on locational attributes of asylum seeker reception.

\footnotetext{
${ }^{4}$ ArcGIS Light Gray Canvas Basemap (v. 10.0) was used as a basic layer in Figure 1.
} 


\section{THEORETICAL FRAMEWORK AND RESEARCH QUESTIONS}

The way opinions and attitudes towards asylum seekers are formed can be traced to a number of factors operating within individuals and their interpersonal environment, as well as factors and actors of influence at different spatial levels, from local to global surroundings. An example of the latter is the influence of the media. Analyses have pointed to the predominant depiction of refugees and asylum seekers by mass media - they are presented either as passive victims, as threats to the culture, security, and welfare of the host country, or as a dehumanised, anonymous (out)group (Greussing and Boomgaarden, 2017; See also: Klocker and Dunn, 2003; Haynes et al., 2005). The predominance of stereotyped interpretations in both tabloid and mainstream media was confirmed, even in the midst of the political and humanitarian crisis ${ }^{5}$ (Greussing and Boomgaarden, 2017).

The analysis of Croatian digital news media articles has pinpointed a shift in the way the situation of the "European Migration crisis" was framed, from a humanitarian rhetoric and discourse to more of a 'security-oriented rhetoric that mobilises fear to legitimize stronger control of national borders' (Bilić et al., 2018: 59). At the level of perceptions, the shift went from a vision of victimised or even macabre migration (De Genova, 2017) to that of an invasive and threatening phenomenon ${ }^{6}$ especially in the context of reporting about the Paris attacks on November $13^{\text {th }}, 2015$ and sexual assaults in Cologne on New Year's Eve of 2016. This reporting style spread moral-related panic in the public, resulting in further securitisation of the issue along the Balkan route (cf. Šelo Šabić, 2017; Petrović, 2018), and presumably to more negative perceptions of people in transit, as threatening "others". Mainstream institutional and media cartographies also favoured a panic-inducing narrative, e.g. representing flows of migrants solely through arrow-symbols invasively directed towards the European continent (Migreurop, 2017) passing forward semiology and data most often released by migration control institutions thereby co-producing or reproducing the discourse of migration invasion.

Media depiction of asylum seekers as a multi-faceted problem can be related to encouraging border maintenance at the level of the nation-state (Hubbard, 2005; See also: Hodge, 2015), and also to local communities' opposition to asylum seeker centres being housed in their vicinity (Hubbard, 2005). In investigating anti-asylum seeker sentiments at the level of a local Australian community, Klocker (2004) found that over $70 \%$ of respondents identified asylum seekers as "illegal immigrants", "unlawful", an "economic burden", a "problem", "unwelcome", and "ungrateful", and rarely selected actively positive descriptors; only $12 \%$ of respondents associated asylum seekers with the term "refugee". Furthermore, in a survey of objections to asylum seeker centres of different sizes in the Netherlands, Lubbers et al. (2006) indicated that people with high incomes feared a decrease in the social and cultural resources of their neighbourhood, based on the perception of a mismatch between their own status and that of asylum seekers. In relation to the concept of NIMBYism, i.e. Not In My Back Yard-ism, Hubbard (2005) argued that the local campaign of opposition to a proposed centre for asylum seekers in Nottinghamshire (UK) could be looked at as defending the privileges of "unmarked" whiteness against the imagined threat of a racialised "other".

Generally, in relation to attitudes toward immigrants and minorities, as stated by Berg (2009), two theoretical perspectives are prevalent in the literature: group threat (conflict) theories and contact theory. Group threat theories suggest that the dominant ethno-racial group may express prejudiced

\footnotetext{
${ }^{5}$ Greussing and Boomgaarden's (2017) analysis of Austrian media during Europe's 2015 “European Migration Crisis" (often also called "refugee crisis") revealed that, apart from the administrative aspects of coping with the arrivals, the previously-established narratives of security threat and economisation were most prominent, while humanitarianism frames and background information on the refugees' situation were less present.

${ }^{6}$ The experimental research of Kalebić Maglica et al. (2018) confirmed framing effect of positive and negative news presentation of "European Migration Crisis" on the attitudes expressed towards migrants.
} 
attitudes if it feels it may lose its social, economic, and political power (See generally: Berg, 2009; Rustenbach, 2010). The literature is largely concentrated on interests and identities as the main sources of attitudes towards immigration-a sense of threat stemming from objective social and economic conditions, or cultural and psychological predispositions, is a necessary prior condition of hostility to immigration (Sides and Citrin, 2007). The economic competition explanation has been widely explored in relation to anti-immigrant attitudes, although the results remain ambiguous in terms of the spatial level considered (Rustenbach, 2010), and personal economic circumstances were found to play little role in opinion formation (Citrin et al., 1997). Socio-psychological factors at the individual level rather than economic or demographic context at the country level were indicated as the dominant influence on preferences about immigration (Sides and Citrin, 2007). Deeply held symbolic attitudes about the nation (identity) and differences among individuals in cultural values and beliefs have been shown to be more important than economic status (material interests) or labourmarket competition (Sides and Citrin, 2007; Hainmueller and Hiscox, 2007). Lubbers et al. (2006) found that perceptions of collective ethnic threat drove objections to asylum centres, lending support to the ethnic competition theory.

Contact theory is based on the contact hypothesis, proposed by G. Allport in 1954. He described different dimensions of contact, which should be explored separately and/or in combination with other dimensions (such as: frequency, duration of contact, and diversity of people included; statuses and roles of people included; social environment and atmosphere of the contact; individual personalities; and areas of contact) to be able to predict how they affected attitudes (Allport, 1954). Noting that intergroup contact usually reduces, but sometimes exacerbates, prejudice, Allport adopted a "positive factors" approach whereby reduced prejudice would result from four positive features of the contact situation. The four factors are: equal status of the groups; common goals between the groups; intergroup cooperation; and the support of authorities, law, or custom (Pettigrew and Tropp, 2005; Pettigrew et al., 2011). Numerous reviews showed general support for contact theory, but some reached more mixed conclusions indicating, for instance, that negative contact does occur, especially when said contact is non-voluntary and threatening (Pettigrew et al., 2011). ${ }^{7}$ Nevertheless, a review of recent advances in intergroup contact theory and research showed that even when Allport's conditions were not met, intergroup contact still diminished prejudice on average (Pettigrew and Tropp, 2005; Pettigrew et al., 2011). While intergroup friendship is especially important, even indirect contact can reduce prejudice or influence pro-immigrant attitudes-via mass media and/or having a friend who has an outgroup friend (Pettigrew et al., 2011), as well as a generally more-educated and ethnically-diverse interpersonal environment (Berg, 2009).

Additionally, more knowledge on minority groups is related to developing more tolerant and friendlier attitudes. The study by Turoy-Smith et al. (2013) on the relationship between contact and prejudice against Indigenous Australians and refugees in Australia indicated that increased contact could reduce prejudice toward outgroups; however, contact alone is not as influential as the quality of interactions. Crawley (2005) reminds us that contact theory focuses on quality of personal contacts of an individual and foreigner, distinguishing between "true acquaintance" and closer and more meaningful encounters (such as friendship) and "casual or superficial contact" happening on the streets in a neighbourhood. Referring to Allport's studies, Fetzer (in Crawley, 2005: 22) contends that meaningful

\footnotetext{
${ }^{7}$ In his pivotal study of disintegration and social revival of American local communities, Putnam (2000) contends that ethnic and cultural diversity which might stem from immigration could actually reduce social capital and solidarity in a sense that individuals of diverse communities might tend to abstain or withdraw from community life and not foster trust and collective action with their neighbours. To some extent this reinforces not only ingroup cohesion, but also stances of ethnocentrism, prejudices and race and class lines of delineation.
} 
contact usually decreases prejudices, while it seems more likely that occasional contact might increase prejudices, because it is oftentimes stripped of meaningful and effective interaction, deeper communication and mutual endeavours for understanding of the "other".

Apart from the nature of the contact, the spatial dimension also matters, i.e. where the contact takes place. Drawing on geographies of encounter, Valentine (2008) explores the significance of "meaningful contact" as contact which changes values and translates into a more general respect for others, showing 'that proximity does not equate with meaningful contact' (p. 334) and that there can be a gap between people's professed values and their practices (such as between civilities in a public place and actual attitudes that come out in a more private space). Changes in attitudes related to changes in spatial contexts (socio-economic and geographical mobility) were also described (Valentine and Sadgrove, 2014), as well as the importance of establishing spaces where participants from different groups can safely explore their differences and shared interests in generating meaningful contact (Mayblin et al., 2016). Building further on the importance of spatial context in which the contact occurs, Piekut and Valentine (2017) stress that contact in more public spaces has the weakest effect on attitudes while the contact occurring in private spaces facilitated through close social ties or involuntary relations affects the attitudes the strongest.

Furthermore, Oliver and Wong (2003) found that the relationship between the size of outgroups and the extent of racial animosity depended on the spatial level considered. In metropolitan areas with greater minority populations, intergroup hostility was higher, while at the neighbourhood level, racial diversity corresponded to lower levels of outgroup prejudice and competition.

Besides the explanations of interethnic attitudes based in specific types of contacts or threat perceptions, socio-demographic factors were often found to influence attitudes. For example, younger, more-educated individuals were observed to hold more positive views toward asylum seekers in Australia (McKay et al., 2012) and people with lower levels of education objected more strongly to asylum seeker centres in the Netherlands (Lubbers et al., 2006). Higher levels of education and occupational skills in twenty-two European countries were associated with greater support for all types of immigration; more-educated respondents were significantly less prejudiced, placed greater value on cultural diversity, and were also more likely to believe that immigration generated benefits for the host economy (Hainmueller and Hiscox, 2007). In testing different explanations for antiimmigrant attitudes, Rustenbach (2010) found that higher education, a left-leaning political orientation, as well as being interested in politics and being part of a left-leaning nation were related to more pro-immigrant attitudes. In addition, previous research has shown that religion can both reduce and worsen prejudice and insecurities towards those on the outside of the community, the socalled "other", depending on circumstance (Karyotis and Patrikios, 2010).

Based on these theoretical approaches multiple measuring scales and questionnaires have been developed, deployed and validated providing resources to investigate similar topics in different surroundings and contexts. This is also one of the reasons why we decided to ground our research within this theoretical framework - to provide a new insight into existing interpretations during the specific context of "European Migration Crisis". Furthermore, recent studies on contemporary migration and asylum policies in Croatia have not yet studied the process of perceptions and attitudes formation from a comparative approach on localities. Geography is remarkably absent from the literature on this issue in Croatia, whereas spatial approaches have long been applied in concordance with migration studies or othering-bordering processes in international research. Therefore, the survey concentrated on the fine-scale of Trnje and Dugave neighbourhoods and their specificities, in order to define how socio-spatial interactions can lead to favourable or prejudiced relationships. 
The research questions, which were used as starting points, were: 1) How are asylum seekers defined by the two groups of respondents? One group being located in close proximity to the asylum seeker reception and accommodation centre, and the other more distant; 2 ) Are there any differences in the attitudes expressed by the two groups of respondents towards asylum seekers? Thereby testing the contact and threat perception hypotheses; and 3) Are there any specific socio-demographic profiles of respondents who are more or less prone to perceive asylum seekers as a threat?

Empirical data collected at the turn of 2015/2016 served as basis to answer these questions.

\section{THE CROATIAN CONTEXT}

This research emerged from the actuality of asylum seeker issues in 2015 and 2016 aiming to describe the perceptions of asylum seekers in regard to their (spatial) proximity (to locals). Since the reception and accommodation centre in Dugave (opened in 2011) is currently one of two possible accommodation centres accessible in Croatia $^{8}$, the possible impacts of its presence in the community were hypothesised to be affecting the perceptions of local residents towards asylum seekers.

The survey was conducted in a specific national context of perception and reception of asylum seekers, rooted in the geopolitical context of the Croatian state, which is still in the process of candidacy to integrate the Schengen area, years after its accession to EU membership ( $1^{\text {st }}$ of July, 2013). Before and through the process of EU accession, the Europeanisation of the Croatian legal framework considerably impacted the national asylum reception structures, practices and official narratives (Baričević, 2013). Notably, the means and practices dedicated to the reception of asylum seekers in the Hotel Porin accommodation centre in Dugave partly derive from EU standards. ${ }^{9}$ Furthermore, various socio-spatial restrictions implemented inside the accommodation centre have fostered perceptions attached to migrants in the surrounding neighbourhood, as was already shown in the case of Hotel Porin (Dujmović, 2015). When some individual and random conflictive situations have occurred since the reception and accommodation centre was established in 2011, national media have decidedly agitated local discontent, through general discourses opposing the presence of asylum seekers hosted in the accommodation centre, who were then described as a massive and threatening group of foreigners - thankfully, there have not been any organised collective protests by locals. These events have undoubtedly contributed to frame the overall atmosphere and general perceptions attached to the presence of asylum seekers, even more in the context of a relatively small capital city (See: Petrović and Pozniak, 2014; Dujmović, 2015).

Another important contextual factor of the research is the timeframe of its implementation. Namely, the survey was conducted during the period referred to as the "European Migration Crisis" ${ }^{10}$, which

\footnotetext{
${ }^{8}$ The reception and accommodation centre in Dugave has the capacity to accommodate around 600 persons. The other reception and accommodation centre is in Kutina, located $80 \mathrm{~km}$ south-east of Zagreb. It was opened in 2006 and is able to offer accommodation to approximately 120 persons (mostly adapted for families).

${ }^{9}$ In the process of Europeanisation, a large part of the literature notes however that the "way of doing things", i.e. the local applications observed in practice in the EU member-states, differ from the top-down Community framework (Radaelli, 2002: 108).

${ }^{10}$ De Genova and Tazzioli (2015: 20) challenge the concept of "Migrant/Refugee Crisis" by questioning its nature as EU crisis of border control and migration management regimes: "crisis therefore corresponds above all to a crisis of sovereignty and the exercise of a power over classifying, naming and partitioning the "migrants"/ "refugees".' The situation of increased and massive arrival and transit of refugees and other forced migrants through the Balkan corridor, also characterised by physical obstructions of some countries to deter them,
} 
occurred in summer 2015 and lasted until the end of the first quarter of 2016. Croatia was one of the countries on the so-called Balkan Route and more than 650,000 forced migrants entered (and passed through) Croatia; only a couple hundred of which applied for asylum and gained the status of asylum seeker. ${ }^{11}$ Georgiou and Zaborowski (2017: 3) postulate that European press framed refugees' and migrants' increased arrival in 2015 as a crisis for Europe, where 'new arrivals were seen as outsiders and different to Europeans: either as vulnerable outsiders or as dangerous outsiders'. The immense media coverage of a wide range of issues related to reception and care of forced migrants also shaped the public perceptions of asylum seekers in Croatia. At the national level, the attention towards migratory phenomena in Croatia in 2015/16 was entirely focussed on the arrivals of newcomers, less on asylum seekers or irregular migrants who were already settled in the country. While the former were largely depicted through humanitarian tonality in mainstream media and political discourse, the latter were made less visible in the public debate on migration. The sudden arrival of thousands of forced migrants in Croatia could have influenced responses in relation to compassioned discourse. This bias was anticipated during the writing of the questionnaire.

There has not yet been systematic research on the attitudes expressed towards asylum seekers in the general Croatian context. Several research studies were focused on specific populations of respondents (e.g. students of the University of Zagreb (Župarić-lljić and Gregurović, 2013); residents of the easternmost parts of Croatia (Gregurović et al., 2016); or perceptions of specific aspects of asylum seeker accommodation and shelter building in two locations outside Zagreb (Benčić et al., 2005; Petrović, 2006; Petrović and Pozniak, 2014). Other research targeted general attitudes towards immigrants and the consequences of immigration, and resulted in a reflection of mostly negative perceptions of immigrants expressed as a synergy of cultural, economic, and security threat perception (Cf. Franc et al., 2010; Šram, 2010; Mesić and Bagić, 2011; Čačić-Kumpes et al., 2012).

Even though one might suppose that Croatia's history of being a socialist country and a part of multiethnic federal state creates an environment open to "new and different", it should be noted that recent studies indicate a clear shift towards more ethnocentric public opinions (cf. Čačić-Kumpes et al., 2014) indicating that new generations express more ethnocentric attitudes and significant closedness (rejection) towards cultural and ethnic diversity in comparison to their parents who were socialised during the former (Yugoslavian) regime. Furthermore, Gallup's new Migrant Acceptance Index places Croatia among ten countries with the lowest acceptance of migrants (together with some other post-socialist countries such as Hungary, Slovakia, Czech Republic etc., Esipova et al., 2017). Another characteristic of contemporary Croatia is its very high ethnic homogeneity. ${ }^{12}$ However, Zagreb as a metropolitan urban space is more ethnically diverse and the probability of contact with people of different ethnicity or religion is much higher than in some other parts of the country. Also, migrants in higher proportions tend to settle in urban areas so the possibility of meaningful encounters (not only incidental and superficial) is more likely to be realised (Andersson et al., 2011) as well as contacts with asylum seekers who are settled there.

\section{METHODS}

\subsection{Sample}

pointed also to the crisis of EU(ropean) values of responsibility sharing and solidarity, and the crisis of the Common European Asylum System.

${ }^{11}$ According to http://www.asylumineurope.org/sites/default/files/resources/balkan route reversed.pdf (p89).

${ }^{12}$ More than $90 \%$ of population of Croatia identify as ethnic Croats and over $85 \%$ declare themselves as Roman Catholic. 
The data were collected during the period from November, 2015 to January, 2016. The survey was conducted as a part of larger project "Etničnost i religija u prostornom kontekstu/Ethnicity and Religion in the Spatial Context" which consisted of several different research segments. ${ }^{13}$ The results presented in this paper are based on a systematic random sample $(\mathrm{N}=299)$ in two selected neighbourhoods of the City of Zagreb: Dugave and Trnje. Each neighbourhood represents a specific surrounding in relation to the proximity of asylum seekers. Namely, Dugave is where the reception and accommodation centre for asylum seekers is located, making more-frequent contact between Zagreb residents and asylum seekers and refugees more likely. In contrast, Trnje is located much closer to the city centre of Zagreb and its residents are perceived, in a sense, as a control group for the purposes of assessing perceptions of asylum seekers. The respondents were selected using the method of random walk and approaching every second household in the neighbourhood until the predefined number of respondents was achieved. Surveys were conducted face-to-face, with an average duration of 40 minutes. Due to the fact that this is a specific and sensitive research subject, the response rate was rather low (30-40\%) and respondents with more radical beliefs were seemingly less represented. Average incidence of missing data per item is $0.33 \%$ (range of missing data per item from $0-7)$.

According to the specific demographic characteristics of respondents, the data indicated a slightly greater representation of female respondents. ${ }^{14}$ The overall mean age of respondents was 40 , and a large proportion of respondents had finished college or higher education, indicating a relatively high education level for the sample (which in return might have had an effect on expressed attitudes). Slightly less than $60 \%$ of the respondents were employed, while slightly over the same proportion perceived their socio-economic status as neither better nor worse than that of the majority. Most of the respondents identified as ethnic Croats and Catholics, expressing a relatively-significant level of religiosity. The distribution of variables representing political orientation showed that the respondents positioned themselves politically in the centre, leaning somewhat towards the left. Furthermore, almost $90 \%$ of respondents did not have experience with any kind of displacement (as refugees or internally displaced persons) and around half of them stated that they had one or more friends of foreign descent. The main differences between the two neighbourhoods were that residents of Dugave tended to be overrepresented by women, were slightly older, in notably higher proportion born in Zagreb, overall less educated, tended toward the right-wing politically, were more religious, and, on average, had fewer friends of foreign descent. There were no other visible differences found between the residents of Dugave and Trnje, relevant to this research.

\subsection{Measures}

Several indicators used for estimation of asylum seeker perception were included in the questionnaire. First, the respondents were asked to describe in their own words (in the form of an open question): whom they define as asylum seekers. In the following question they were asked to estimate the countries of origin of the asylum seekers. These two open questions were accompanied by two questions aimed at determining whether the respondents had ever met an asylum seeker and defining the first source of their information on the subject of asylum seekers (offering several possible answers: educational system; media; NGOs; state institutions; and other).

\footnotetext{
${ }^{13}$ The project included segments such as perception and social distance expressed towards Roma in Northern Croatia and Zagreb, perception of asylum seekers and refugees, and an analysis of the relations between religious and political territories with a special focus on the role of border between them.

${ }^{14} \mathrm{~A}$ detailed description of the sample and subsamples based on city neighbourhoods can be found in Appendix 1.
} 
In order to determine the perception of asylum seekers, two Likert-type scales were used. ${ }^{15}$ The first scale aimed to explore general attitudes towards asylum seekers and consisted of 25 items based on several conducted studies (See: Župarić-lljić and Gregurović, 2013; Gregurović et al., 2016; Cf. Pedersen et al., 2006; Klocker and Dunn, 2003; Kerwin, 2005; McDonald, 2008; Koutroulis, 2009). Besides the direct connection to the employed theoretical concepts, the decision to use these measures and scales lies in their validation in previously-conducted research and ability to compare with the obtained results. In this paper, the scale of asylum seeker perception was used in the form of derived dimensions of perception, based on the results of conducted exploratory factor analysis (EFA). Overall, 14 items yielded 4 dimensions: 1$)$ the social contact dimension (6 items); 2) the economy/health dimension ( 3 items); 3 ) the ethnocultural similarity dimension ( 3 items); and 4 ) the asylum seeker credibility estimation dimension ( 2 items). ${ }^{16}$ The first dimension refers to social contact described as an expression of social distance, indicating the respondents' willingness to welcome and make contact with asylum seekers and refugees, as well as possibly offering help or granting the right to practice their own cultural traditions. The second dimension reflects the perception of asylum seekers in the domain of economy and health. The third dimension points towards a preference for similarity between asylum seekers and refugees and the domestic population, as well as an expression of relatively high ethnic distance from them. Finally, the fourth dimension indicates a higher perception of asylum seekers as economic migrants in pursuit of a better life, denying them their actual status as refugees or asylum seekers. Even though the items were formulated both positively and negatively to minimise the acquiescent and extreme response bias, the final direction of the composite scale was determined by the results of the factor analysis.

The second Likert-type scale was used to describe attitudes based on locational attributes of asylum seeker reception (Cf. Župarić-lljić and Gregurović, 2013; Hubbard, 2005; Lubbers et al., 2006; Zorlu, 2016). Out of 16 items, 12 were included in the final rotated solution of exploratory factor analysis, which resulted in two orthogonal dimensions: 1 ) Reception/residential preferences (7 items) and 2) Perception of asylum seeker reception policies (5 items). The first dimension refers to speaking in favour of pronounced ethnic distance and desire for dislocation of reception centres for asylum seekers. However, since the scale included more items with a positive inclination towards asylum seeker reception the whole indicator was oriented towards positive perception. The second dimension refers to national reception policies implying that the state should ensure adequate reception of asylum seekers, offering them, as well as the local population, greater security; but it also implies an expression of humanitarianism by ensuring better reception conditions and better quality of life. This dimension also involves a possible reduction of tax burden by utilising empty state properties.

As independent variables, which were used to describe the major perceptions of asylum seekers and the respondents' attitudes based on locational attributes of asylum seeker reception in the analyses, the aforementioned socio-demographic, socio-economic, and socio-cultural characteristics of respondents were included. The results were then compared according to the neighbourhoods of the respondents in order to test the hypothesis of contact (Allport, 1954; Tropp and Pettigrew, 2005; Tropp, 2007).

\subsection{Statistical procedures}

The open-ended questions referring to the general definitions of asylum seekers were subjected to open (initial) coding. Open coding represented the first step of qualitative analysis and it referred to ascribing the initial codes (labels) to the answers. Conceptual categories were derived from the initial codes in the next step of the analysis (Khandkara, n.d.; Holton, 2010). This method implies encoding

\footnotetext{
${ }^{15}$ The answer scales used in both instruments ranged from 1 - Strongly disagree to 5 - Strongly agree.

${ }^{16}$ EFA indicators and all items measuring attitudes towards asylum seekers and attitudes based on locational attributes of asylum seeker reception included in the EFAs, as well as their descriptive statistics, can be found in Appendix 2.
} 
of one or more response segments-depending on the complexity of the response-which results in one or more codes being assigned to each response. For instance, if the respondent defined an asylum seeker as a refugee fleeing from poverty, this answer was given two different codes: the first code referring to the term refugee and the second to the reason for leaving the home country. The codes were developed in parallel with data analysis, i.e. they were created at each encounter with a new term or concept. In total, 9 different codes were assigned to the open answers to the question on the defining asylum seekers (seekers of international protection) (for a detailed description, see Table 1 in Results section). Since the codes themselves indicate a specific level of conceptualisation and contextualisation we did not proceed by creating categories. The second open question on the country of asylum seekers origin was handled in a similar manner, and was coded by eight specific codes (see Table 2 in Results section). The $\chi^{2}$ test was used to determine possible differences in the answers to these two questions among the residents of two neighbourhoods. The purpose of the analysis of these questions is entirely descriptive.

As presented in the previous section, latent constructs of attitudes towards asylum seekers and attitudes based on locational attributes of asylum seeker reception were analysed using EFA (Principal component method, GK criterion of factor extraction, and Varimax rotation ${ }^{17}$ ). The results of the factor analysis served as a basis for the construction of dependent composite variables, which were further used as criterion variables in multiple regression analysis. The regression analyses were conducted in order to determine specific characteristics of respondents prone to expressing positive or negative attitudes towards asylum seekers and/or their reception. A t-test, based on respondents' location of residence, was used to further analyse the effect of proximity to asylum seekers in the expressed attitudes. Finally, a Pearson correlation was used to determine the relation between the latent dimensions of two attitudinal constructs.

\subsection{Limitations of this research study}

The obtained specifics of sample(s) - especially the one in Dugave (e.g. greater inclusion of female and older respondents) fit the profile of respondents more prone to participate in the survey. However, these characteristics might affect the presented results so they could not be referred as entirely representative of the neighbourhood. Furthermore, the formulation of the questions (like the formulation of news) in a positive or negative way leaves an impression on the respondent, and can make them more or less inclined to express a specific attitude. Variation between positive and negative items might have reduced the extreme responses and acquiescence bias but it also could have contributed to decreased internal consistency of the scales (Salazar, 2014). Finally, having in mind cross-sectionality of the study, conducting the survey during the "European Migration Crisis" allows us to interpret the results within this specific context so generalisations on some other, contextually more neutral situations could not be based in these findings. However, this research could also come to be viewed in a positive manner, as a contribution to description of attitude formation within a specific, contextually highly-correlated situation to the subject at hand.

\section{RESULTS}

\subsection{General definition of asylum seekers and sources of information on the subject of asylum}

\footnotetext{
17 Varimax rotation was used to obtain independent dimensions of certain value-attitude spaces and to avoid possible suppression in multiple regression (Čulig, 2005: 224).
} 
Definitions of asylum seekers provided by respondents were categorised using nine different codes. Since the respondents could assign more than one attribute to asylum seekers, they were all separately coded, and the sum of all codes presented in the Table 1. The proportion of each individual code has been calculated in regard to the total number of respondents. Among the 440 codes assigned in the definitions of asylum seekers, the most common was that of a person fleeing because of fear of persecution based on religious, ethnic or political affiliation, or personal beliefs. In other words, the most common basically-recognised definition of asylum seekers and asylees (See: Convention Relating to the Status of Refugees, 1951) was stressed by more than one-third of the respondents. Furthermore, asylum seekers were defined by one-quarter of respondents as persons in pursuit of a new homeland, searching for security, protection, help, or shelter. However, almost the same proportion of respondents (24\%) perceived them as persons in pursuit of better life. The least mentioned attributions were economic migration or those with negative connotations such as asylum seekers being labelled as terrorists.

\begin{tabular}{|c|c|c|}
\hline & $\begin{array}{c}\text { Number of codes } \\
\text { assigned }\end{array}$ & $\begin{array}{l}\% \text { of total number of } \\
\text { respondents (299) }\end{array}$ \\
\hline $\begin{array}{l}\text { Fleeing because of fear of persecution } \\
\text { (religious, ethnic, or political) }\end{array}$ & 106 & 35.45 \\
\hline $\begin{array}{l}\text { In pursuit of a new homeland, security, } \\
\text { protection, help, rights, or shelter }\end{array}$ & 77 & 25.75 \\
\hline In pursuit of a better life & 71 & 23.75 \\
\hline Fleeing from war & 50 & 16.72 \\
\hline Refugees & 39 & 13.04 \\
\hline Fleeing from poverty and deprivation & 31 & 10.37 \\
\hline Terrorists and other negative connotations & 17 & 5.69 \\
\hline Economic migrants & 12 & 4.01 \\
\hline Other & 37 & 12.37 \\
\hline $\begin{array}{ll} & \text { Total } \\
\end{array}$ & 440 & \\
\hline
\end{tabular}

Table 1. Definition of asylum seekers

The most common definitions of asylum seekers were ${ }^{18}$ :

'Persons in pursuit of better life outside their home country, fleeing from religious or political persecution' (D003).

'Persons fleeing from their country for some reason (war, economic issues), and seeking protection in another state-maybe also a better life' (D027).

'Persons who emigrate from their country due to political, economic, religious reasons and seek asylum in another country' (T203).

No statistically significant difference was found between the residents of the two neighbourhoods in expressing a general definition of asylum seekers $\left(\chi^{2}=14.278 ; \mathrm{df}=8 ; \mathrm{p}=0.075\right)$, however, residents of Dugave tended to define asylum seekers more as persons fleeing because of the fear of persecution

${ }^{18}$ Questionnaires were in Croatian. Illustrative responses have been translated to English. 
(religious, ethnic, or political) and fleeing from war; while residents of Trnje perceived asylum seekers, in a larger proportion, as persons in pursuit of new homeland, security, protection, help, rights, or shelter.

When it came to estimating country of origin of asylum seekers, most respondents defined countries using geographical information as their main reference. Conversely, the second set of definitions relates to some contextual attributions of the country of origin. In total, 506 codes were assigned to the respondents' answers, and high proportions of respondents relied on geographical definitions in estimating that countries of the Middle East (62\%) and/or countries of Africa (46.5\%) were the likely countries of origin of asylum seekers. Contextual references such as war, unfavourable economic conditions, or political instability were not used in such high proportions (7-17\%). Even more respondents combined several characteristics of countries in their responses, for instance: "Warafflicted areas (Syria, Iraq, and Afghanistan), poor African countries" (D113) or "Poorly-developed countries, often affected by war" (T200).

\begin{tabular}{|l|c|c|}
\hline & $\begin{array}{c}\text { Number of codes } \\
\text { assigned }\end{array}$ & $\begin{array}{c}\text { \% of total number of } \\
\text { respondents (299) }\end{array}$ \\
\hline $\begin{array}{l}\text { Geographical definition: countries of the } \\
\text { Middle East }\end{array}$ & 186 & 62.21 \\
\hline Geographical definition: countries of Africa & 139 & 46.49 \\
\hline Geographical definition: others & 63 & 21.07 \\
\hline Contextual definition: war & 50 & 16.72 \\
\hline $\begin{array}{l}\text { Contextual definition: unfavourable } \\
\text { economic situation }\end{array}$ & 23 & 7.69 \\
\hline Contextual definition: political instability & 20 & 6.69 \\
\hline Arab/Muslim countries & 15 & 5.02 \\
\hline Other & 10 & 3.34 \\
\hline
\end{tabular}

Table 2. Estimation of countries of origin of the asylum seekers

Again, no statistically significant difference was found between the residents of the two neighbourhoods in determining the country of origin of asylum seekers $\left(\chi^{2}=6.691 ; d f=7 ; p=0.462\right)$; however, the patterns expressed in general definition of asylum seekers were also visible in greater proportions when defining countries of origin in a contextual manner, as war afflicted, in Dugave.

In the introductory part of the questionnaire, two other general questions were posed. The first referred to personal contact with asylum seekers or asylees, and the second referred to the respondent's first source of information on the subject of asylum. Almost three quarters of respondents (74\%) had never met or been introduced to an asylum seeker or asylee. However, a statistically significant difference, found between the respondents of two neighbourhoods, indicated that residents of Dugave had met asylum seekers or asylees in much higher proportion $(32.4 \%)$ than the residents of Trnje had $(18 \%)\left(\chi^{2}=8.057 ; \mathrm{df}=1 ; \mathrm{p}=0.005\right)$.

As the first source of information on the subject of asylum, the largest portion of respondents stressed media (62\%). Only $13 \%$ indicated educational system as the first source, while state institutions and nongovernmental organisations were indicated by less than $2 \%$ of respondents. A significant proportion, especially in case of Dugave residents (30\%), indicated "other" where they defined their 
answers more specifically as personal contact or information obtained from their surroundings such as nearby reception centre or in the neighbourhood. ${ }^{19}$ Some residents of Dugave described their personal contact using the special context as "met in bus" or "found them trespassing" but the incidence of such specific description of contact was extremely low and inappropriate for any further analyses.

\subsection{Attitudes towards asylum seekers}

The attitudes towards asylum seekers on a latent level can be defined into four distinct dimensions. Each dimension has been presented as a composite variable based on the items loading each dimension (i.e. the sum of all items within a single factor). To enable clearer presentation and comparison, the composite variables have been recoded into five categories. Figure 2 displays the distribution of each dimension divided by the residential location of respondents.

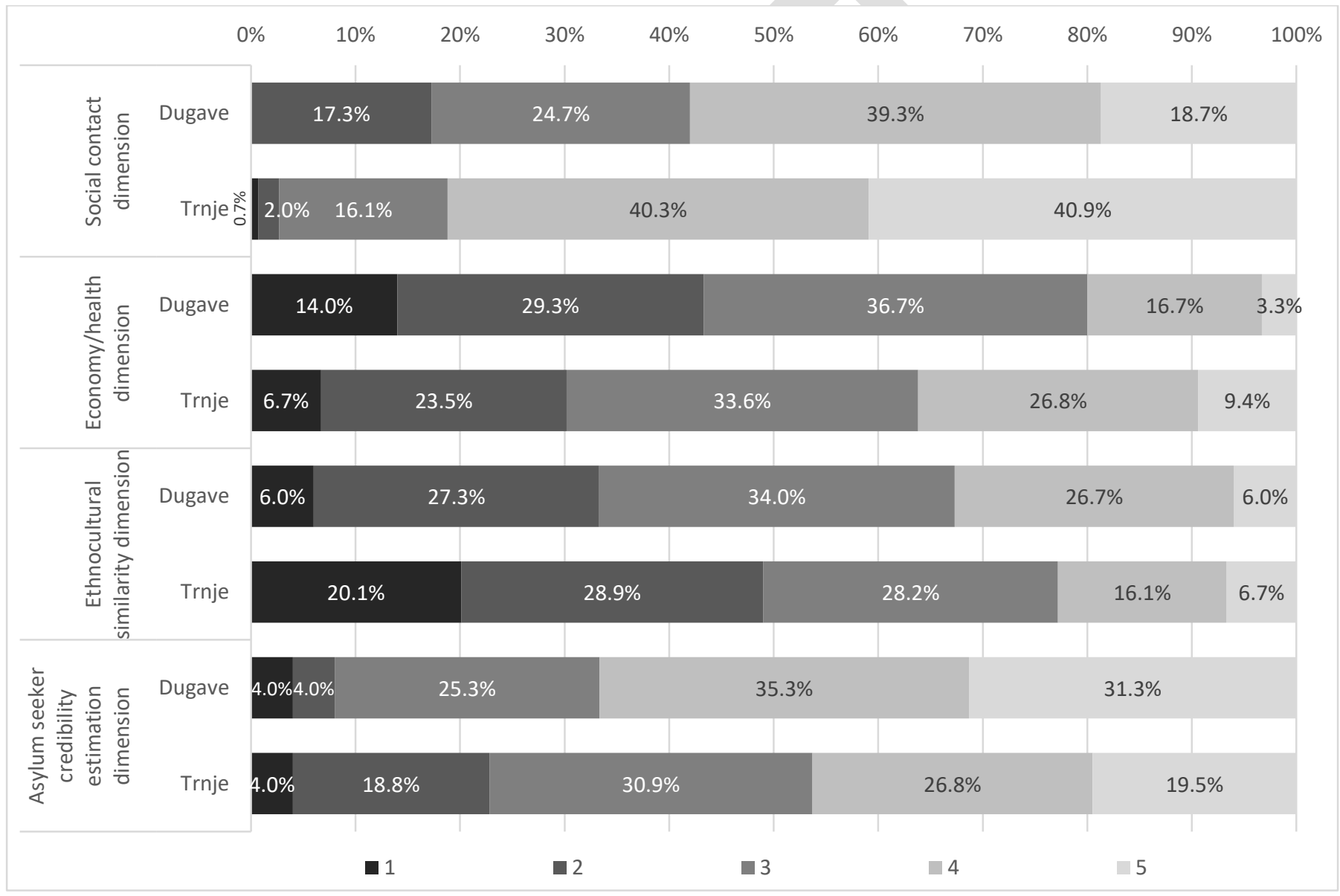

Figure 2. Distribution of the dimensions of attitudes towards asylum seekers according to neighbourhood

The obtained results indicate the differences in distributions of all dimensions of attitudes towards asylum seekers between the residents of the neighbourhoods in question. These differences have been confirmed by t-test, aimed at testing the average perceptions of residents of the neighbourhoods in question, regarding each dimension. Residents of Dugave, to a greater extent, expressed stronger ethnic distance (from asylum seekers), which is visible from the higher proportions in the categories

\footnotetext{
19 These results were also confirmed by the statistically significant difference found between residents of the two neighbourhoods in question, regarding the first source of information on asylum $\left(\chi^{2}=15.466 ; d f=4 ; p=0.004\right)$.
} 
on the left side of Figure 2, indicating more negative perceptions of asylum seekers within the dimension of social contact. ${ }^{20} \mathrm{~A}$ similar result was obtained for the economy/health dimension, where residents of Dugave perceived asylum seekers as a greater health and economic threat than did the residents of Trnje. ${ }^{21}$ The two groups of respondents are also differentiated regarding the other two dimensions. The distribution of preferences for ethnocultural similarity of asylum seekers to the local population indicate that the residents of Trnje perceived it as less important. This group of respondents also perceived asylum seekers as more genuine in comparison to the views of the residents of Dugave, who, in larger proportions, related asylum seekers to economic migrants in pursuit of better life. ${ }^{22}$

The locational differences were further analysed according to the results of the regression analyses. The same predictor model was used to predict all dimensions of attitudes towards asylum seekers, but separately for the two groups of respondents according to their neighbourhood. Eleven sociodemographic, socio-economic, and socio-cultural indicators (such as age, gender, education, socioeconomic status (SES), and political orientation) were used as predictors together with three contextual variables: prior experience of displacement, having one or more friends of foreign descent and media as the first source of information about asylum. The results are presented in parallel for each dimension by neighbourhood to enable clearer comparisons (Table 3).

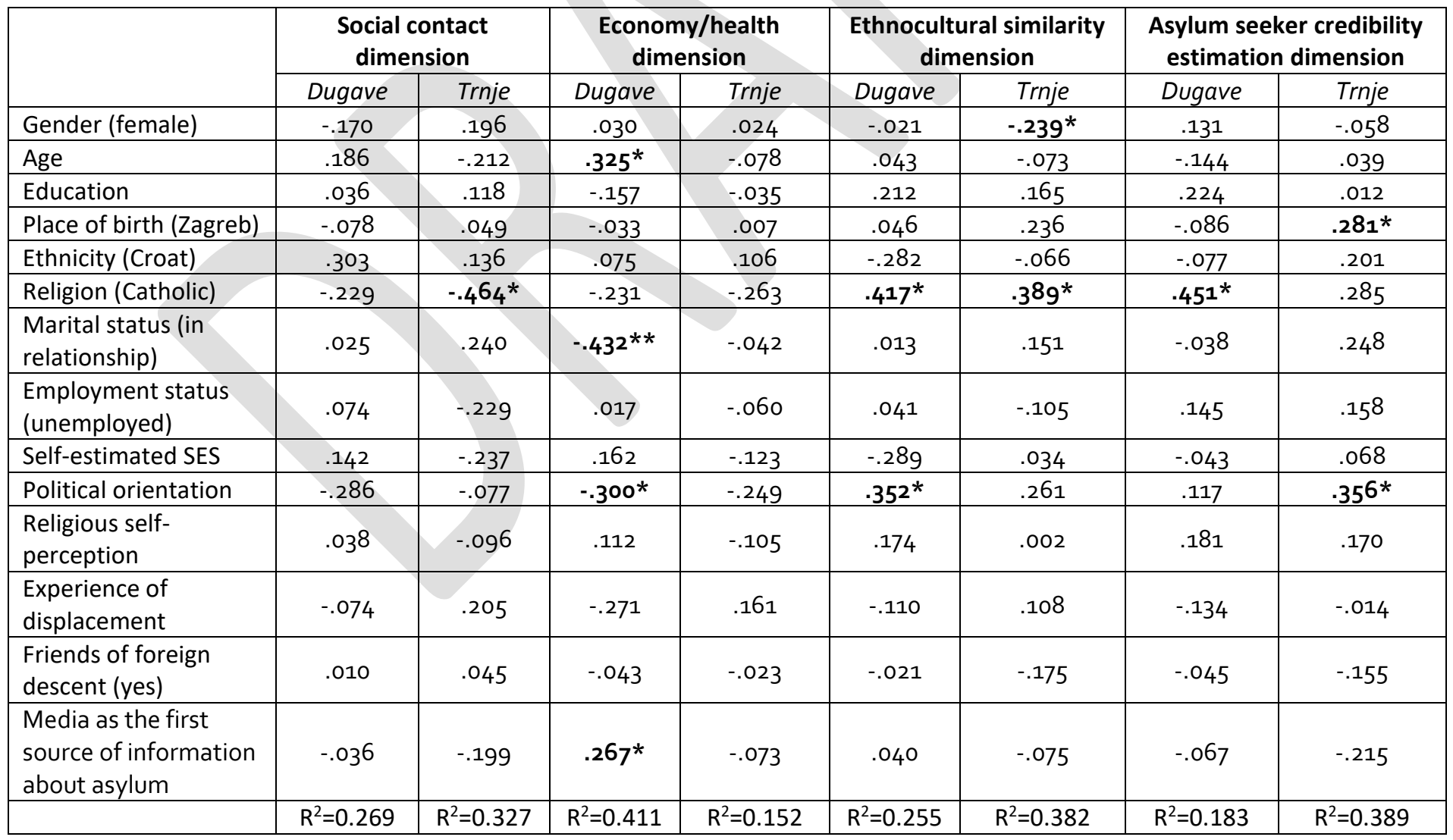

\footnotetext{
${ }^{20}$ The result has also been confirmed by a statistically significant $t$-test ( $\left.t=-5.664 ; d f=288.90 ; p=0.000\right)$, according to which residents of Dugave have a lower average result of the social contact dimension $\left(M_{D}=3.59 ; S D_{D}=0.984\right)$ in comparison to residents of Trnje ( $\left.\mathrm{M}_{\mathrm{T}}=4.19 ; \mathrm{SD}_{\mathrm{T}}=0.825\right)$.

${ }^{21}$ The statistically significant t-test confirmed the differences in distributions of the economy/health dimension $(\mathrm{t}=-3.528 ; \mathrm{df}=297 ; \mathrm{p}=0.000)$.

${ }^{22}$ The differences in distributions of both dimensions were additionally confirmed by the statistically significant $\mathrm{t}$-test (Ethnocultural similarity dimension: $\mathrm{t}=3.070$; $\mathrm{df}=290.30 ; \mathrm{p}=0.002$; Asylum seeker credibility estimation dimension: $t=3.774 ; d f=294.95 ; p=0.000)$.
} 


\begin{tabular}{|l|l|l|l|l|l|l|l|l|}
\hline & $F=1.233$ & $F=1.771$ & $F=2.344$ & $F=0.652$ & $F=1.152$ & $F=2.255$ & $F=0.750$ & $F=2.322$ \\
& $p=0.285$ & $p=0.070$ & $p=0.015$ & $p=0.808$ & $p=0.342$ & $p=0.018$ & $p=0.715$ & $p=0.015$ \\
\hline
\end{tabular}

$* p<0.05 ; * *<<0.01$

\section{Table 3. Effects on attitudes towards asylum seekers: Regression analysis}

Even though a stronger effect of selected predictor indicators was expected, seven variables significantly contributed to explaining the dependent dimensions of attitudes towards asylum seekers. In Table 3, it can be seen that the selected predictor model explained a quite reasonable proportion of variance in almost all presented combinations of dependent variables and subsamples, however, the model was statistically significant in predicting only three dependent variables ${ }^{23}$ : the Economy/health dimension in the Dugave sample (41.1\% of variance explained), the Ethnocultural similarity dimension in the Trnje sample (38.2\% of variance explained) and the Asylum seeker credibility estimation dimension in the Trnje sample (38.9\% of variance explained). The three models, which were not significant overall, yielded several significant predictors, which will also be addressed later in the paper. In total, the seven significant predictor variables were gender, age, place of birth, religion, marital status, political orientation, and media as the primary source of information about asylum. According to gender, the obtained results indicate that the male residents of Trnje favour ethnocultural similarity more than women from same neighbourhood. Older respondents from Dugave perceive asylum seekers as a greater economic/cultural threat as well as those respondents from Dugave who indicate media as their primary source of information on asylum. Residents from Trnje born in Zagreb perceive asylum seekers as less genuine than the respondents born elsewhere. Moreover, Catholics from Trnje expressed stronger ethnic distance and undesirability of social contact, and stronger preference of ethnocultural similarity to asylum seekers in comparison to other religious denominations. Catholics of Dugave also stressed desirability of ethnocultural similarity of asylum seekers to the local population as well as estimated asylum seekers to be illegitimate, i.e. economic migrants. Furthermore, respondents from Dugave who were not in (marital) relationships perceived asylum seekers as an economic/health threat to a lesser extent. Finally, respondents from Dugave, who were more right-wing oriented politically, perceived a greater economic/health threat and preferred asylum seekers to have more ethnocultural similarity, while respondents from Trnje, of a similar political persuasion, estimated asylum seekers as non-credible more often than the politically left-wing oriented respondents from same neighbourhood.

\subsection{Attitudes based on locational attributes of asylum seeker reception}

Same set of analyses conducted on attitudes towards asylum seekers was also applied to attitudes based on locational attributes of asylum seeker reception. Additionally, the connection of two attitudinal constructs was analysed. The two obtained dimensions of attitudes based on locational attributes indicated that the respondents of both neighbourhoods estimated the locational attributes of asylum seeker reception are quite normally distributed, even though residents of Dugave indicated, in higher proportions, their reluctance to live near asylum seeker reception centres. This result was also confirmed by the t-test, which indicated that, on average, residents of Dugave expressed more negative attitudes related to reception of asylum seekers and their residential preferences $(t=-2.812$; $d f=294.06 ; p=0.005)$. Similar results were obtained on the second dimension of perception of asylum seeker reception policies. A higher proportion of residents from Trnje estimated that the state should be more involved in securing acceptable accommodation for asylum seekers. ${ }^{24}$

\footnotetext{
${ }^{23}$ The lack of the statistical significance of regression models could be ascribed to the small subsamples.

${ }^{24}$ The result has also been confirmed by the statistically significant $t$-test $(t=-4.746 ; d f=297 ; p=0.000)$.
} 


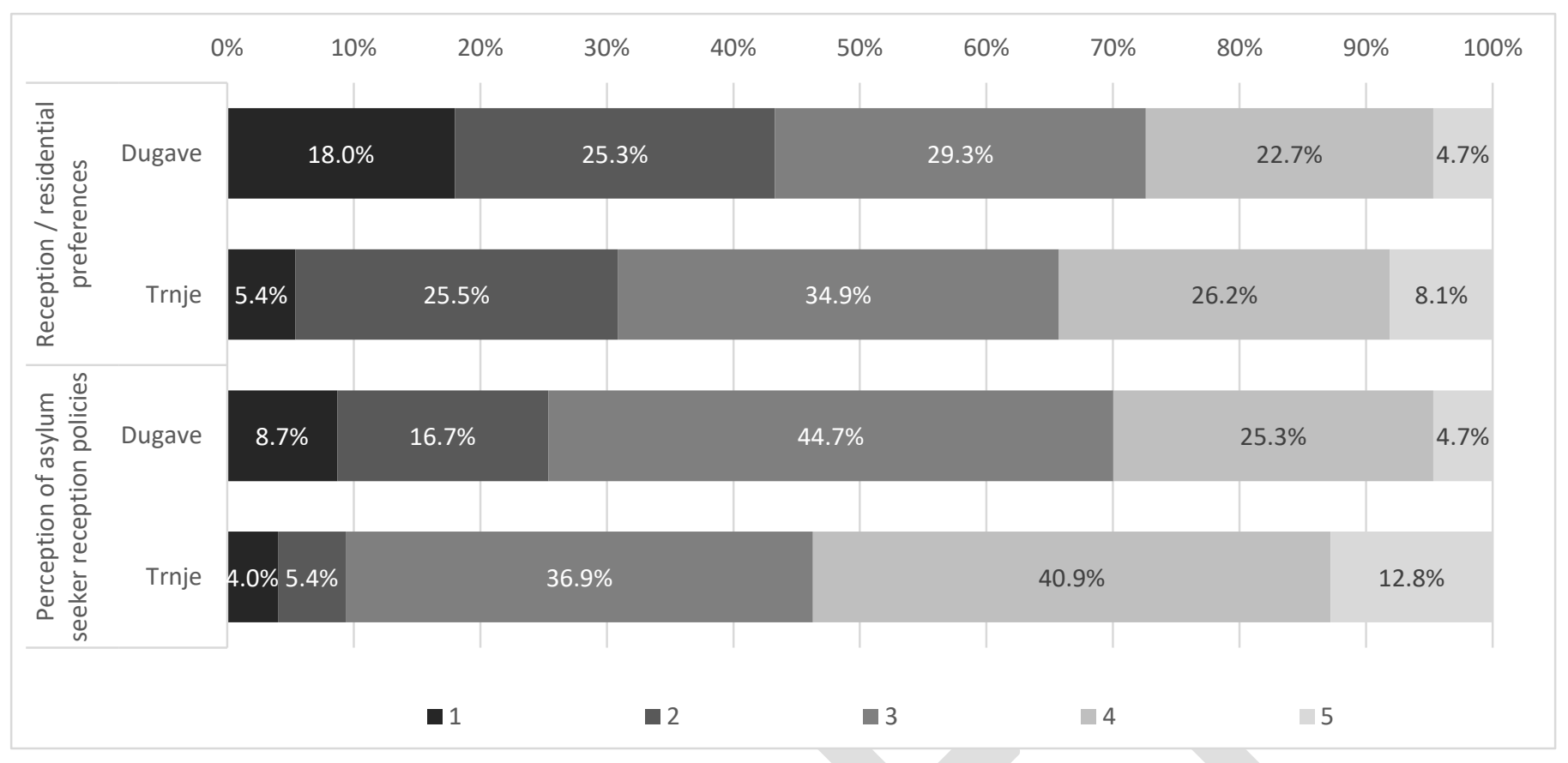

Figure 3. Distributions of the dimensions of attitudes based on locational attributes of asylum seeker reception according to neighbourhood

The same predictor model, as in the analysis of general attitudes towards asylum seekers, was applied in the regression analysis to explain the dimensions of attitudes based on locational attributes of asylum seeker reception. The model only explains the dimension of reception/residential preferences of Dugave residents as statistically significant ( $44.6 \%$ of variance explained). The respondents who did not desire to live close to asylum seekers were largely respondents born in Zagreb, Catholics and those who indicated the media as their primary source of information about asylum. In contrast, even though the overall model was not statistically significant, residents of Trnje who were not Catholics indicated that the state should grant acceptable accommodation of good quality to asylum seekers in Croatia.

\begin{tabular}{|l|c|c|c|c|}
\hline \multirow{2}{*}{} & \multicolumn{2}{|c|}{$\begin{array}{c}\text { Reception / residential } \\
\text { preferences }\end{array}$} & \multicolumn{2}{c|}{$\begin{array}{c}\text { Perception of asylum } \\
\text { seeker reception policies }\end{array}$} \\
\cline { 2 - 4 } & Dugave & Trnje & Dugave & Trnje \\
\hline Gender (female) & -.054 & .166 & .222 & .190 \\
\hline Age & .117 & -.198 & .204 & .003 \\
\hline Education & -.072 & .032 & .090 & .024 \\
\hline Place of birth (Zagreb) & $-.352^{* *}$ & -.045 & -.124 & -.116 \\
\hline Ethnicity (Croat) & .171 & -.021 & .190 & .106 \\
\hline Religion (Catholic) & $-.597^{* *}$ & -.187 & -.167 & $-.446 *$ \\
\hline Marital status (in relationship) & -.188 & .168 & -.323 & .013 \\
\hline Employment status (unemployed) & -.015 & -.146 & -.052 & -.100 \\
\hline Self-estimated SES & .077 & -.071 & .264 & -.185 \\
\hline Political orientation & -.226 & -.191 & -.088 & -.133 \\
\hline Religious self-perception & -.336 & .152 & .154 & -.082 \\
\hline Experience of displacement & -.114 & .043 & -.179 & .142 \\
\hline Friends of foreign descent (yes) & -.213 & .009 & -.117 & .059 \\
\hline
\end{tabular}




\begin{tabular}{|l|c|c|c|c|}
\hline $\begin{array}{l}\text { Media as the first source of } \\
\text { information about asylum }\end{array}$ & $.293^{*}$ & -.022 & .059 & .058 \\
\hline & $\mathrm{R}^{2}=0.446$ & $\mathrm{R}^{2}=0.283$ & $\mathrm{R}^{2}=0.315$ & $\mathrm{R}^{2}=0.220$ \\
& $\mathrm{~F}=2.697$ & $\mathrm{~F}=1.438$ & $\mathrm{~F}=1.546$ & $\mathrm{~F}=1.027$ \\
& $\mathrm{p}=0.006$ & $\mathrm{p}=0.170$ & $\mathrm{p}=0.132$ & $\mathrm{p}=0.443$ \\
\hline
\end{tabular}

Table 4. Effects on attitudes based on locational attributes of asylum seeker reception: Regression analysis

As a final analysis, used to determine interrelations between the obtained latent dimensions of two analysed attitudinal constructs, Pearson's correlation coefficients were calculated (Table 5). All correlations were statistically significant with values ranging from medium negative to high positive. The strongest correlations were obtained between the first dimension of attitudes towards asylum seekers and both dimensions of attitudes based on locational attributes of asylum seeker reception, indicating that the respondents, who, within the dimension of social contact, tended to perceive asylum seekers more positively and were willing to make contact with them, were also more open to living close to them and showed more support for adequate institutional involvement in their reception and accommodation in Croatia. Additionally, respondents who perceived asylum seekers as a greater economic and health threat expressed a weaker preference for living in the same neighbourhood with asylum seekers and were not inclined to support the idea of state-organised reception facilities. A similar intensity of correlation was obtained for the next set of indicators, according to which the respondents who preferred ethnocultural similarity of asylum seekers tended to express more negative attitudes regarding their personal residential preferences connected to asylum seeker reception and state policies on asylum seeker reception. Finally, the weakest correlations were obtained between the last latent dimension of attitudes towards asylum seekersthe credibility estimation and the two dimensions of locational attributes of asylum seeker reception; respondents who perceived asylum seekers as less-credible and who identified them as primarily economic migrants, expressed a weaker desire to live in close proximity and perceived the state's role in ensuring the adequate reception of asylum seekers not to be a priority.

\begin{tabular}{|l|c|c|}
\hline & $\begin{array}{c}\text { Reception/residential } \\
\text { preferences }\end{array}$ & $\begin{array}{c}\text { Perception of } \\
\text { asylum seeker } \\
\text { reception policies }\end{array}$ \\
\hline Social contact dimension & $.638^{* *}$ & $.637^{* *}$ \\
\hline Economy/health dimension & $.564^{* *}$ & $.427^{* *}$ \\
\hline Ethnocultural similarity dimension & $-.574^{* *}$ & $-.440^{* *}$ \\
\hline Asylum seeker credibility estimation dimension & $-.399^{* *}$ & $-.337^{* *}$ \\
\hline
\end{tabular}

$* * \mathrm{p}<0.001$

Table 5. Correlations between the dimensions of the two attitudinal constructs

\section{DISCUSSION AND CONCLUSION}

The most common definition of asylum seekers, given by over a third of the respondents, was that of a person fleeing due to fear of persecution, in line with the 1951 Convention Relating to the Status of Refugees. Asylum seekers were also often defined as persons in pursuit of a new homeland, searching for security, protection, help, or shelter. Our results show that a significantly higher percentage of respondents in this study saw asylum seekers as refugees and people in need of protection, in comparison to some previous studies (See: Klocker, 2004). However, this finding may also be 
interpreted in relation to the time frame of the survey, during the "European Migration Crisis" of 2015, when the issues of asylum seekers became one of the main topics in the media and day-to-day discussion. This corresponds to the high percentage of respondents who named media as their primary source of information on the subject of asylum and asylum seekers (62\%), pointing to the importance of media representations. Social media discourse played a complementary role to politicians in shaping the atmosphere of welcome and solidarity during the first two months of massive arrivals and transit of refugees through Croatia. However, as in European context from 2016, the media also turned into an actor promoting dehumanisation and stereotyping of refugees, suppressing the welcoming culture, and lessening levels of empathy and compassion, as emphasised by Gill (2018). This is also evident from the obtained results of regression analyses which indicate that media, as the primary source of information about asylum and asylum seekers, has had a significant (and negative) effect on the respondents from Dugave-the neighbourhood accommodating asylum seekers-who perceived asylum seekers as a greater economic/health threat and were less inclined to live in the same neighbourhood where reception centre is located.

Still, almost a quarter of the respondents ${ }^{25}$ in our study perceived asylum seekers as persons in pursuit of a better life. Although "in pursuit of a better life" does not necessarily mean "better life for economic reasons", it may be looked at in the context of a distinction observable in popular, political, and academic discourse-between a "deserving" and genuine refugee and "undeserving" migrant or "fraud refugee". As Crawley and Skleparis (2017) contend through "politics of bounding", diverse categories and classifying concepts are constructed in order to administratively differentiate those who are deserving of protection, and those who are less-deserving or un-deserving. Throughout the experience of the large scale transit through Balkan route in 2015/16 it became obvious that politicians and the media portrayals of the complexity of forced migration served a specific function in which boundaries between different administrative categories were construed and conveyed as a sort of categorical fetishism in order to establish a hierarchical system of rights, 'used to distinguish, divide and discriminate between those on the move', as pointed out by Crawley and Skleparis (2017: $4,8)$.

(Im)migrants, as opposed to refugees, tend to be portrayed as economic opportunists in search of a better life, which often positions them as unworthy of social, economic, and political rights (Holmes and Castañeda, 2016). Furthermore, the results of the surveys conducted in Netherlands showed that Dutch citizens expressed greater support for immigration policies when they felt sympathy for "real (political) refugees", while they supported restrictive policies if they felt angry with "fake (economic) refugees" (Verkuyten, 2004). Interestingly, McKay et al. (2012) found that more than half of all respondents in a country-wide survey thought that asylum seekers came to Australia "for a better life" and about one quarter to "flee persecution". The way that media adopts negativity and specific references of the government in relation to asylum seekers was extensively explored in the case of Australia (Klocker and Dunn, 2003), as well as influences of problematic, negative and stereotypical, government/political, and media constructions on negative perceptions of asylum seekers (Klocker, 2004; McKay et al., 2012). Furthermore, popularised labels constructed through negative political/media discourse, such as "queue jumpers", "terrorists", "boat people" and "illegals", tended to shift public view away from the structural reasons for asylum seeking (McKay et al., 2012). Research suggests that media has strong effect on shaping less positive attitudes towards refugees and migrants, because media can encourage negative latent feelings towards newcomers: '(...) the media

\footnotetext{
25 This percentage is even higher when the categories of economic migrants, and those fleeing poverty and deprivation are added (almost 40\%)
} 
produces a sense of powerless among the white majority: that there is nothing to be done about the issues that concern them' (Valentine and McDonald, 2004, in Crawley, 2005: 30).

It seems that the first two months of increased arrivals, in the Croatian context (September and October 2015), were characterised by the use of the terms "refugees" and "forced migrants". Later on, along with racial profiling of those who were allowed to trespass through Croatia (first and foremost Syrian nationals)-and especially after the event of Paris terrorist attack-concepts of migrants became prominently used. Dealing with refugees and migrants in transit was characterised in a specific form of securitarian humanitarianism (Petrović, 2018) presented to the public only by media portrayals. After the corridor ceased to exist (officially in March 2016), the movement of people in need of protection through the Balkan route continued, but then they were characterised as "undeserving illegal/irregular migrants", once more inducing mainly securitisation discourses and portrayals in the media, and among politicians. This has clear policy implications on envisaging more inclusive reception and sensible measures regarding the public and local communities in which reception and accommodation facilities are located.

The majority of respondents in this study used their knowledge of geography to define the countries of origin of asylum seekers (Middle Eastern and/or African countries), while to a smaller degree respondents used contextual references such as war and unfavourable economic or political conditions. No statistically significant differences between the residents of the two neighbourhoods were found in terms of definition of asylum seekers or their country of origin. However, as was expected due to the location of the asylum seeker reception and accommodation centre, residents of Dugave indicated, in a much higher proportion (32.4\%), that they had met an asylum seeker or asylee in comparison to the residents of Trnje (only 18\%); and a significant proportion of Dugave residents listed personal contact or information obtained from their surroundings as their first source of information on the subject of asylum. The results indicate that in case of Dugave casual contacts of locals with asylum seekers are more frequent than true acquaintances, and in case of Trnje these meaningful contacts are even less present. Therefore, it seems that the mere fact of knowing someone from outgroup is not enough to postulate a significant reduction of prejudice towards that group or a drastic change in values, but the quality of that contact may be: 'whilst negative individual "encounters" tend to produce powerful negative generalisations, positive encounters do not work in the same way', warns Crawley (2005: 24).

Thus, regarding the location and contact with asylum seekers, i.e. how it affected attitudes of Trnje and Dugave residents, significant differences were found on all latent dimensions of attitudinal constructs: residents of Dugave expressed, in general, more negative attitudes towards asylum seekers and their reception in Croatia. They expressed a stronger ethnic distance (within the dimension of social contact), and perceived asylum seekers as a greater health and economic threat than did the residents of Trnje. Furthermore, Trnje residents placed less importance on ethnocultural similarity of asylum seekers to the local population and perceived asylum seekers as more genuine, in comparison to the residents of Dugave who, to a greater extent, related asylum seekers to economic migrants in pursuit of a better life. These findings indicate that location, i.e. residing in the same neighbourhood, is not enough to decrease prejudice; and they may also be interpreted in terms of lending support to Allport's (1954) claim that occasional and accidental contact often results in increased, rather than reduced, prejudice, as well as the quality of interactions (i.e. meaningful contact) being more important than increased contact by itself (See: Turoy-Smith et al., 2013; Crawley, 2005). It is more likely that prejudice will be diminished if the intergroup contact is not superficial and group salience is sufficiently high (Pettigrew et al., 2011). 
McHugh-Dillon (2015) cites several Australian studies, which identified demographic characteristics associated with attitudes towards asylum seekers, where, overall, males, people with lower levels of formal education, and people who described their political views as right-wing were more likely to express negative attitudes than women, younger people, the more highly educated, and people who characterised themselves as left-wing. In this study, several socio-demographic indicators explain four latent dimensions of attitudes towards asylum seekers. In total, the obtained results showed that the male residents of Trnje placed more importance on ethnocultural similarity than women did, while respondents from Dugave, who were not in a (marital) relationship, perceived asylum seekers as less of an economic/health threat. Catholics from Trnje expressed a stronger ethnic distance and a preference for ethnocultural similarity of asylum seekers, as did Dugave Catholics, who also estimated asylum seekers to be illegitimate, i.e. economic migrants. In comparison, in their survey in the Netherlands, Lubbers et al. (2006) found that frequent church attenders objected somewhat less to asylum seeker centres than non-attenders. On the other hand, Karyotis and Patrikios (2010) found that religiosity was a strong predictor of anti-immigration attitudes in Greece and that exposure to securitising religious discourse immunised 'churchgoers from the softening effect of the political message' (p. 44) implying that religious elites were influential in the process of securitisation of migration especially in countries where national and religious identities were closely interwoven, like in Greece and Croatia. These findings could be further interpreted as support for the ethnic competition theory; in line with previous research, where it was established that the way traditional values, norms, and national identity were conceptualised, and what could potentially pose a threat to these values, also influenced attitudes towards asylum seekers (McKay et al., 2012; Klocker, 2004; See also: McHugh-Dillon, 2015).

Apart from religious denomination, political orientation was another strong predictor, where the politically more right-wing oriented Dugave respondents perceived a greater economic/health threat and preferred more ethnocultural similarity of asylum seekers; while politically right-wing oriented respondents from Trnje estimated asylum seekers more often as non-credible. Similarly, other research (Semyonov et al., 2006; Pedersen et al., 2005) also resulted in findings that left-oriented respondents expressed mostly (more) positive attitudes towards immigrants in comparison to respondents who listed their political inclination as right and extremely right-wing. These results could be interpreted within the theory of right-wing authoritarianism, according to which expressing prejudice and negative attitudes toward outgroups are ascribed to motivational interests connected to group cohesion, stability, and security (Altemeyer, 2006).

Residents of Dugave also, in higher proportions, indicated their reluctance to live near asylum seeker reception centres, pointing to the well-known NIMBY logic among residents already living in the neighbourhood where the reception centre is located. Similarly, Chamboredon and Lemaire (1970) pointed out that the spatial proximity of coexisting heterogeneous groups (in context of population formation in social housing complexes in France) accentuated developmental contrasts, implying greater social distance, and possibly division and conflict. These findings disagree with those of Lubbers et al. (2006), who found that people who lived in neighbourhoods where an asylum seeker centre was located, had fewer objections to these centres. The respondents who did not desire to live close to asylum seekers were largely those born in Zagreb, Catholics, and those listing media as the first source of information about asylum. In addition, non-Catholic residents of Trnje perceived that the state should grant accommodation of good quality to asylum seekers in Croatia. These results again stress the significant influence of media on perception of making the neighbourhood even less desirable to live in. 
Respondents who, within the dimension of social contact, tended to perceive asylum seekers more positively and were willing to make contact with them, were also more open to living close by and showed more support for adequate institutional involvement in their reception and accommodation. Conversely, respondents who perceived asylum seekers as a greater economic and health threat, those who preferred ethnocultural similarity of asylum seekers, and those who perceived asylum seekers as less credible and primarily identified them as economic migrants, expressed a weaker desire to live in the same neighbourhood with them and did not support state-organised asylum seeker reception. Referring to the Anderson's concept of struggle for Selfhood, Hubbard (2005: 60) indicates that 'socio-spatial exclusion of asylum seekers draws on an established language of abjection which serves to differentiate between "threatened Self" and "threatening Other" (...) with anxieties about the integrity of Self projected on to racialized Others who are then repressed, excluded or contained.' However, in the case of Croatia, besides some individual and incidental voices against the location of Reception and Accommodation centre in Dugave, there have not been any organised protests by locals against asylum seekers in that part of the city, and it seems that local community cherishes a relatively peaceful coexistence with the centre and its inhabitants.

Although simultaneous use of two theoretical approaches often sets the framework of defining ethnic (cultural) harmony in interethnic contacts and ethnic (cultural) intolerance and hostility when a threat is perceived (Dixon, 2006), we could not help but wonder whether contact in this particular case has had the opposite effect and served as confirmation of prejudice, rather than a reduction, indicating the better fit of the meaningful encounter approach in interpretation of the results. Even though the obtained results should be approached with caution, since the sample included is rather small and not entirely representative of the targeted neighbourhoods, they set a starting point for further research on subject of asylum seeker perception, which should preferably be conducted on a larger scale, i.e. on the national and/or international scale. That said, the presented findings could also be used as a link to the results of previous research conducted in Croatia, offering a comparative and longitudinal perspective on investigating attitudes towards asylum seekers. Even though the presence of asylum seekers from far-away territories of Asia, especially the Middle-East and Africa, is still a relatively new phenomenon in Croatian society, thanks to media portrayals and in light of possible future relocations and resettlements of asylum seekers and refugees from other European countries, it has been gradually becoming the part of Croatian reality and everyday life. Therefore, the results of this study could also serve as a basis for initiating programmes for raising awareness in local communities positioned closer to asylum seeker reception and accommodation centres, as well as for informing and educating the general public on the presence, rights, and needs of international asylum seekers.

\section{REFERENCES}

Allport, G. W., 1954. The Nature of Prejudice. Addison-Wesley Publishing, Cambridge.

Altemeyer, B., 2006. The Authoritarians. University of Manitoba, Winnipeg.

Andersson, J., Vanderbeck, R. M., Valentine, G., Ward, K., Sadgrove, J., 2011. New York encounters: religion, sexuality, and the city. Environment and Planning A 43, 618-633, doi: 10.1068/a43202

Baričević, V., 2013. Europeanization of Asylum System and Refugee Protection: Croatian Asylum and Migration Policies. PhD dissertation, University of Ljubljana.

Barlow, F. K., Paolini, S., Pedersen, A., Hornsey, M. J., Radke, H. R. M., Harwood, J., Rubin, M., Sibley, C. G., 2012. The Contact Caveat: Negative Contact Predicts Increased Prejudice More Than Positive 
Contact Predicts Reduced Prejudice. Personality and Social Psychology Bulletin 38 (12), 1629-1643, doi: $10.1177 / 0146167212457953$

Betts, A. and Collier, P., 2017. Refuge: Transforming a Broken Refugee System. Penguin Random House, London.

Berg, J. A., 2009. Core Networks and Whites' Attitudes toward Immigrants and Immigration Policy. Public Opinion Quarterly 73 (1), 7-31, doi: 10.1093/poq/nfp011

Bilić, P., Furman, I., Yildirim, S., 2018. The Refugee Crisis in the Croatian Digital News: Towards a Computational Political Economy of Communication. The Political Economy of Communication 6 (1), 59-82.

Census of Population, Households and Dwellings (2011). Zagreb: Croatian Bureau of Statistics.

Chamboredon J-C., Lemaire M., 1970. Proximité spatiale et distance sociale. Les grands ensembles et leur peuplement. Revue française de sociologie 11 (1), 3-33.

Citrin, J., Green, D. P., Muste, C., Wong, C., 1997. Public Opinion toward Immigration Reform: The Role of Economic Motivations. The Journal of Politics 59 (3), 858-881.

Crawley, H., 2005. Evidence on Attitudes to Asylum and Immigration: What We Know, Don't Know and Need to Know. Centre on Migration, Policy and Society, Working Paper No. 23, University of Oxford.

Crawley, H., Skleparis, D., 2017. Refugees, migrants, neither, both: categorical fetishism and the politics of bounding in Europe's 'migration crisis'. Journal of Ethnic and Migration Studies 44 (1), 4864, doi: 10.1080/1369183X.2017.1348224

Čačić-Kumpes, J. Gregurović, S. and Kumpes, J., 2012. Migracija, integracija i stavovi prema imigrantima u Hrvatskoj. Revija za sociologiju 42 (3), 305-336.

Čačić-Kumpes, J., Gregurović, M., Kumpes, J., 2014. Generacijske razlike u odnosu prema etničkoj različitosti: stavovi hrvatskih srednjoškolaca i njihovih roditelja. Revija za sociologiju 44 (3), 235-285, doi: $10.5613 /$ rzs.44.3.2

Čulig, B., 2005. Analiza procjene aktualnih društvenih i političkih problema u Hrvatskoj. Socijalna ekologija 14 (3), 217-234.

De Genova, N., 2017. Introduction. In: De Genova, N. (Ed.) The Borders of "Europe": Autonomy of Migration, Tactics of Bordering. Duke University Press, Durham and London, 1-35, Unpublished manuscript, https://www.opendemocracy.net/beyondslavery/nicholas-de-genova/border-spectacleof-migrant-\%E2\%80\%98victimisation\%E2\%80\%99

De Genova, N., Tazzioli, M. (Eds.), 2015. Europe/Crisis. New Keywords of "the Crisis" in and of "Europe". Available at: http://nearfuturesonline.org/wp-content/uploads/2016/01/New-KeywordsCollective_11.pdf

Dixon, J. C., 2006. The Ties That Bind and Those That Don't: Toward Reconciling Group Threat and Contact Theories of Prejudice. Social Forces 84 (4): 2179-2204.

Dujmović, M., 2016. Du refuge au camp : habiter les territoires des centres pour demandeurs d'asile en Croatie. In : Canepari, E., Mesini, B., Mourlane, S. (Eds.). Mobil hom(m)es, formes d'habitats et modes d'habiter la mobilité (XVle-XXle siècles), éditions de l'Aube, Paris, pp. 35-44. 
Esipova, N, Fleming, J., Ray, J., 2017. New Index Shows Least-, Most-Accepting Countries for Migrants, news.gallup.com, August 23, 2017, Available at:

https://news.gallup.com/poll/216377/new-index-shows-least-accepting-countries-migrants.aspx

Georgiou, M., Zaborowski, R. 2017. Media Coverage of the Refugee Crisis: A Cross-European Perspective. Council of Europe Report, April 2017. https://rm.coe.int/1680706b00

Gregurović, M., Kuti, S., Župarić-Iljić, D., 2016. Attitudes towards Immigrant Workers and Asylum Seekers in Eastern Croatia: Dimensions, Determinants and Differences. Migracijske i etničke teme 32 (1), 91-122, doi: 10.11567/met.32.1.4.

Greussing, E., Boomgaarden, H. G., 2017. Shifting the refugee narrative? An automated frame analysis of Europe's 2015 refugee crisis. Journal of Ethnic and Migration Studies 43 (11), 1749-1774, doi: 10.1080/1369183X.2017.1282813

Gill, N., 2018. The suppression of welcome. Fennia 196 (1), 88-98, doi: 10.11143/fennia.70040

Hainmueller, J., Hiscox, M. J., 2007. Educated Preferences: Explaining Attitudes toward Immigration in Europe. International Organization 61 (2), 399-442, doi: 10.1017/\$0020818307070142

Haynes, A., Breen, M., Devereux, E., 2005. "Smuggling Zebras for Lunch": Media Framing of Asylum Seekers in the Irish Print Media. Études irlandaises 30 (1), 109-130, doi: 10.3406/irlan.2005.2997

Haubert, J., Fussell, E., 2006. Explaining Pro-Immigrant Sentiment in the U.S.: Social Class, Cosmopolitanism, and Perceptions of Immigrants. International Migration Review 40 (3): 489-507, doi: 10.1111/j.1747-7379.2006.00033.x

Hodge, P. (2015). A grievable life? The criminalisation and securing of asylum seeker bodies in the 'violent frames' of Australia's Operation Sovereign Borders. Geoforum 58, 122-131, doi: 10.1016/j.geoforum.2014.11.006

Holmes, S. M., Castañeda, H., 2016. Representing the "European refugee crisis" in Germany and beyond: Deservingness and difference, life and death. American Ethnologist 43 (1), 12-24, doi: 10.1111/amet.12259

Holton, J. A., 2010. The Coding Process and Its Challenges. The Grounded Theory Review 9 (1), 21-40. Hubbard, P., 2005. Accommodating Otherness: anti-asylum centre protest and the maintenance of white privilege. Transactions of the Institute of British Geographers 30 (1), 52-65, doi: 10.1111/j.1475-5661.2005.00151.x

Kalebić Maglica, B., Švegar, D., Jovković, M., 2018. Odnos osobina ličnosti, efekta okvira i stavova prema migrantima. Društvena istraživanja 27 (3), 495-517, doi: 10.5559/di.27.3.06

Karyotis, G., Patrikios, S., 2010. Religion, securitization and anti-immigration attitudes: The case of Greece. Journal of Peace Research 47 (1), 43-57, doi: 10.1177/0022343309350021

Kerwin, D., 2005. The use and misuse of 'national security' rationale in crafting U.S. refugee and immigration policies. International Journal of Refugee Law 17 (4), 749-763, doi: 10.1093/ijrl/eei030

Khandkara, S. H., n.d. Open Coding. http://www.ssnpstudents.com/wp/wp-

content/uploads/2015/02/open-coding.pdf.

Klocker, N., 2004. Community Antagonism towards Asylum Seekers in Port Augusta, South Australia. Australian Geographical Studies 42 (1), 1-17, doi: 10.1111/j.1467-8470.2004.00239.x 
Klocker, N., Dunn, K. M., 2003. Who's driving the asylum debate? Newspaper and government representations of asylum seekers. Media International Australia 109, 71-92.

Koutroulis, G., 2009. Public health metaphors in Australian policy on asylum seekers. Australian and New Zealand Journal of Public Health 33 (1), 47-50, doi: 10.1111/j.1753-6405.2009.00337.x

Lubbers, M., Coenders, M., Scheepers, P., 2006. Objections to Asylum Seeker Centres: Individual and Contextual Determinants of Resistance to Small and Large Centres in the Netherlands. European Sociological Review 22 (3), 243-257, doi: 10.1093/esr/jci055

Mayblin, L., Valentine, G., Andersson, J., 2016. In the contact zone: engineering meaningful encounters across difference through an interfaith project. The Geographical Journal 182 (2), 213222, doi: 10.1111/geoj.12128

McDonald, M., 2008. Securitization and the construction of security. European Journal of International Relations 14 (4), 563-587, doi: 10.1177/1354066108097553

McHugh-Dillon, H., 2015. 'If they are genuine refugees, why?' Public attitudes to unauthorised arrivals in Australia. Foundation House, The Victorian Foundation for Survivors of Torture, http://www.foundationhouse.org.au/wp-content/uploads/2015/07/Public-attitudes-tounauthorised-arrivals-in-Australia-Foundation-House-review-2015.pdf

McKay, F. H., Thomas, S. L. Kneebone, S., 2012. 'It Would be Okay If They Came through the Proper Channels': Community Perceptions and Attitudes toward Asylum Seekers in Australia. Journal of Refugee Studies 25 (1), 113-133, doi: 10.1093/jrs/fer010

Mesić, M., Bagić, D., 2011. Stavovi hrvatskih građana prema kulturnim različitostima. Migracijske i etničke teme 27 (1), 7-38.

Migreurop, 2017. Atlas des migrants en Europe. Approches critiques des politiques migratoires. 3rd Edition, Armand Colin, Paris.

Oliver, J. E., Wong, J., 2003. Intergroup Prejudice in Multiethnic Settings. American Journal of Political Science 47 (4), 567-582, doi: 10.1111/1540-5907.00040

Pedersen, A., Attwell, J., Heveli, D., 2005. Prediction of negative attitudes toward Australian asylum seekers: False beliefs, nationalism, and self-esteem. Australian Journal of Psychology 57 (3), 148-160, doi: 10.1080/00049530500125157

Pedersen, A., Watt, S., Hansen, S., 2006. The role of false beliefs in the community's and the federal government's attitudes toward Australian asylum seekers. Australian Journal of Social Issues, 41 (1), 105-124.

Petrović, D., 2018. Humanitarian Exceptionalism: Normalization of Suspension of Law in Camp and Corridor. In: Bužinkić, E., Hameršak, M. (Eds.). Formation and Disintegration of the Balkan Refugee Corridor: Camps, Routes and Borders in Croatian Context. Institute of Ethnology and Folklore Research, Centre for Peace Studies, Faculty of Political Science University of Zagreb - Centre for Ethnicity, Citizenship and Migration, bordermonitoring.eu e.V., Zagreb - München, pp. 43-62.

Petrović, D., Pozniak, R., 2014. Tražitelji azila kao prijetnja. Studia ethnologica Croatica 26 (1), 47-72, doi: $10.17234 /$ SEC.26.3 
Pettigrew, T. F., Tropp, L. R., 2005. Allport's Intergroup Contact Hypothesis: Its History and Influence. In: Dovidio, J. F., Glick, P., Rudman, L. A. (Eds.) On the Nature of Prejudice: Fifty Years after Allport. Blackwell Publishing, Malden - Oxford - Carlton, pp. 262-277.

Pettigrew, T. F., Tropp, L. R., Wagner, U., Christ, O., 2011. Recent advances in intergroup contact theory. International Journal of Intercultural Relations 35 (3), 271-280, doi: 10.1016/j.ijintrel.2011.03.001

Piekut, A., Valentine, G., 2017. Spaces of encounter and attitudes towards difference: A comparative study of two European cities. Social Science Research 62, 175-188, doi:

10.1016/j.ssresearch.2016.08.005

Putnam, R., 2000. Bowling Alone: The Collapse and Revival of American Community. Simon \& Schuster, New York.

Radaelli, C., 2002. The Domestic Impact of European Union Public Policy: Notes on Concepts, Methods, and the Challenge of Empirical Research. Politique européenne 1 (5), 105-136.

Rustenbach, E., 2010. Sources of Negative Attitudes toward Immigrants in Europe: A Multi-Level Analysis. International Migration Review 44 (1), 53-77, doi: 10.1111/j.1747-7379.2009.00798.x

Salazar, M.S., 2014. The dilemma of combining positive and negative items in scales. Psicothema 27 (2), 192-199, doi: 10.7334/psicothema2014.266

Semyonov, M., Raijman, R., Gorodzeisky, A., 2006. The rise of antiforeigner sentiment in European societies, 1988-2000. American Sociological Review 71 (3), 426-449, doi:

$10.1177 / 000312240607100304$

Sides, J., Citrin, J., 2007. European Opinion about Immigration: The Role of Identities, Interests and Information. British Journal of Political Science 37 (3), 477-504.

Šelo Šabić, S., 2017. The Impact of the Refugee Crisis in the Balkans: A Drift Towards Security. Journal of Regional Security 12 (1), 51-74.

Tropp, L. R., 2007. Perceived Discrimination and Interracial Contact: Predicting Interracial Closeness among Black and White Americans. Social Psychology Quarterly 70 (1), 70-81.

Tropp, L. R., Pettigrew, T. F., 2005. Differential Relationships between Intergroup Contact and Affective and Cognitive Dimensions of Prejudice. Personality and Social Psychology Bulletin 31 (8), $1145-1158$.

Turoy-Smith, K. M., Kane, R., Pedersen, A., 2013. The willingness of a society to act on behalf of Indigenous Australians and refugees: the role of contact, intergroup anxiety, prejudice, and support for legislative change. Journal of Applied Social Psychology 43 (S2), E179-E195, doi: 10.1111/jasp.12017

Valentine, G., 2008. Living with difference: reflections on geographies of encounter. Progress in Human Geography 32 (3), 323-337, doi: 10.1177/0309133308089372

Valentine, G., Sadgrove, J., 2014. Biographical Narratives of Encounter: The Significance of Mobility and Emplacement in Shaping Attitudes towards Difference. Urban Studies 51(9), 1979-1994, doi: 10.1177/0042098013504142 
van Kempen, R., Wissink, B., 2014. Between places and flows: towards a new agenda for neighbourhood research in an age of mobility. Geografiska Annaler: Series B, Human Geography 96 (2), 95-108, doi: 10.1111/geob.12039

Verkuyten, M., 2004. Emotional reactions to and support for immigrant policies: attributed responsibilities to categories of asylum seekers. Social Justice Research 17 (3), 293-314, doi: 10.1023/B:SORE.0000041295.83611.dc

Zorlu, A., 2016. Attitudes toward Asylum Seekers in Small Local Communities. International Migration, http://onlinelibrary.wiley.com/doi/10.1111/imig.12296/full, doi: 10.1111/imig.12296

Župarić-Iljić, D., Gregurović, M., 2013. Stavovi studenata prema tražiteljima azila u Republici Hrvatskoj. Društvena istraživanja 22 (1), 41-62, doi: 10.5559/di.22.1.03.

APPENDIX 1 - Sample descriptives

\begin{tabular}{|c|c|c|c|c|c|}
\hline Variable & Categories & $\begin{array}{c}\text { Total - } \\
\mathbf{N}\end{array}$ & $\begin{array}{c}\text { Total - } \\
\% \\
\end{array}$ & $\begin{array}{c}\text { Dugave - \% } \\
(\mathrm{N}=150)\end{array}$ & $\begin{array}{c}\text { Trnje - \% } \\
(\mathrm{N}=149)\end{array}$ \\
\hline \multirow{2}{*}{ Gender } & Male & 140 & 46.8 & 43.3 & 50.3 \\
\hline & Female & 158 & 52.8 & 56.0 & 49.7 \\
\hline \multirow{4}{*}{ Age } & 30 years or younger & 109 & 36.5 & 38.7 & 34.2 \\
\hline & $31-45$ years & 83 & 27.8 & 20.0 & 35.6 \\
\hline & $46-60$ years & 72 & 24.1 & 27.3 & 20.8 \\
\hline & 61 years or older & 35 & 11.7 & 14.0 & 9.4 \\
\hline \multicolumn{2}{|l|}{ Average age } & \multicolumn{2}{|c|}{$\begin{array}{l}M=39.78 \\
S D=15.160\end{array}$} & $\begin{array}{l}M=40.62 \\
S D=15.917\end{array}$ & $\begin{array}{l}M=38.93 ; \\
S D=14.361\end{array}$ \\
\hline \multirow{2}{*}{ Place of birth } & Zagreb & 174 & 58.2 & 68.0 & 48.3 \\
\hline & Others & 125 & 41.8 & 32.1 & 51.6 \\
\hline \multirow{2}{*}{ Ethnicity } & Croats & 281 & 94 & 94.0 & 94 \\
\hline & Others & 11 & 3.7 & 3.3 & 4.0 \\
\hline \multirow{3}{*}{$\begin{array}{l}\text { Religious } \\
\text { denomination }\end{array}$} & Catholic & 288 & 76.3 & 82.0 & 70.5 \\
\hline & Other & 14 & 4.7 & 3.3 & 6.0 \\
\hline & Atheists & 29 & 9.7 & 8.0 & 11.4 \\
\hline \multirow[t]{2}{*}{ Marital status } & $\begin{array}{l}\text { Single (not married, } \\
\text { divorced, widowed) }\end{array}$ & 153 & 51.2 & 48.6 & 53.8 \\
\hline & In relationship & 145 & 48.5 & 50.7 & 46.3 \\
\hline \multirow{3}{*}{ Education } & Primary school or lower & 10 & 3.3 & 5.3 & 1.3 \\
\hline & Secondary school & 138 & 46.2 & 51.3 & 40.9 \\
\hline & College or higher & 148 & 49.5 & 41.3 & 57.7 \\
\hline \multirow{3}{*}{ Employment status } & Employed & 175 & 58.5 & 59.3 & 57.7 \\
\hline & Unemployed & 21 & 7.0 & 6.0 & 8.1 \\
\hline & $\begin{array}{l}\text { Others (retired, } \\
\text { students, housewives) }\end{array}$ & 100 & 33.4 & 33.4 & 33.6 \\
\hline Self-estimated SES & Lower than the majority & 26 & 8.7 & 8.0 & 10.4 \\
\hline
\end{tabular}




\begin{tabular}{|c|c|c|c|c|c|}
\hline & $\begin{array}{l}\text { Neither better nor } \\
\text { worse than the majority }\end{array}$ & 189 & 63.2 & 62.0 & 64.4 \\
\hline & Better than the majority & 81 & 27.1 & 28.0 & 26.2 \\
\hline \multirow{5}{*}{ Political orientation } & Left & 33 & 11.0 & 12.0 & 10.1 \\
\hline & Left centre & 59 & 19.7 & 14.0 & 25.5 \\
\hline & Centre & 62 & 20.7 & 20.7 & 20.8 \\
\hline & Right centre & 32 & 10.7 & 8.7 & 12.8 \\
\hline & Right & 34 & 11.4 & 14.0 & 8.7 \\
\hline \multirow{6}{*}{$\begin{array}{l}\text { Religious self- } \\
\text { perception }\end{array}$} & Convinced believer & 84 & 28.1 & 36.7 & 19.5 \\
\hline & Religious & 99 & 33.1 & 28.7 & 37.6 \\
\hline & Uncertain & 24 & 8.0 & 6.7 & 9.4 \\
\hline & Indifferent & 34 & 11.4 & 9.3 & 13.4 \\
\hline & $\begin{array}{l}\text { Not religious - has } \\
\text { nothing against religion }\end{array}$ & 45 & 15.1 & 14.7 & 15.4 \\
\hline & $\begin{array}{l}\text { Not religious - against } \\
\text { religion }\end{array}$ & 8 & 2.7 & 1.3 & 4.0 \\
\hline \multirow{2}{*}{$\begin{array}{l}\text { Experience of } \\
\text { displacement }\end{array}$} & Yes & 35 & 11.7 & 11.4 & 12.1 \\
\hline & No & 262 & 87.6 & 87.3 & 87.9 \\
\hline \multirow{2}{*}{$\begin{array}{l}\text { Friends of foreign } \\
\text { descent }\end{array}$} & Yes, one or more & 164 & 54.8 & 52.0 & 57.7 \\
\hline & No & 132 & 44.1 & 46.0 & 42.3 \\
\hline
\end{tabular}

\section{APPENDIX 2 - Scale descriptives}

\section{1) Descriptives - Attitudes towards AS}

\begin{tabular}{|c|c|c|c|c|c|c|c|c|c|c|}
\hline & & 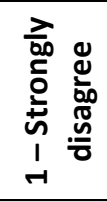 & 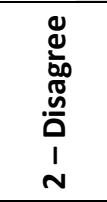 & 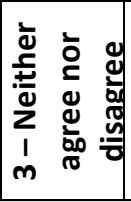 & 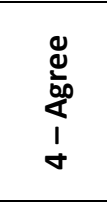 & 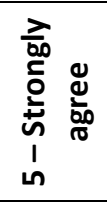 & $\mathbf{N}$ & $M$ & SD & 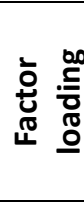 \\
\hline \multicolumn{11}{|c|}{ Factor 1 - Dimension of social contact (Cronbach's alpha of the composite scale $=0.814$ ) } \\
\hline \multirow{2}{*}{$\begin{array}{l}\text { 13. I would have helped asylum } \\
\text { seekers if I could. }\end{array}$} & Dugave & $5.4 \%$ & $8.2 \%$ & $21.8 \%$ & $27.2 \%$ & $37.4 \%$ & 147 & 3.83 & 1.178 & \multirow{2}{*}{.787} \\
\hline & Trnje & $2.0 \%$ & $2.0 \%$ & $11.4 \%$ & $21.5 \%$ & $63.1 \%$ & 149 & 4.42 & .916 & \\
\hline \multirow{2}{*}{$\begin{array}{l}\text { 18. I am willing to talk to an } \\
\text { asylum seeker who would stop } \\
\text { me on the street. }\end{array}$} & Dugave & $9.3 \%$ & $8.7 \%$ & $18.7 \%$ & $27.3 \%$ & $36.0 \%$ & 150 & 3.72 & 1.291 & \multirow{2}{*}{.758} \\
\hline & Trnje & $2.0 \%$ & $3.4 \%$ & $7.4 \%$ & $20.9 \%$ & $66.2 \%$ & 148 & 4.46 & 0.921 & \\
\hline \multirow{2}{*}{$\begin{array}{l}\text { 14. Asylum seekers to not } \\
\text { present threat to the Croatian } \\
\text { national unity. }\end{array}$} & Dugave & $14.7 \%$ & $11.3 \%$ & $26.0 \%$ & $19.3 \%$ & $28.7 \%$ & 150 & 3.36 & 1.387 & \multirow{2}{*}{.669} \\
\hline & Trnje & $2.7 \%$ & $10.1 \%$ & $14.1 \%$ & $24.2 \%$ & $49.0 \%$ & 149 & 4.07 & 1.131 & \\
\hline \multirow{2}{*}{$\begin{array}{l}\text { 6. I would not mind inviting } \\
\text { asylum seeker to my home to } \\
\text { hand out. }\end{array}$} & Dugave & $27.5 \%$ & $19.5 \%$ & $20.8 \%$ & $14.1 \%$ & $18.1 \%$ & 149 & 2.76 & 1.455 & \multirow{2}{*}{639} \\
\hline & Trnje & $12.8 \%$ & $12.8 \%$ & $22.1 \%$ & $18.1 \%$ & $34.2 \%$ & 149 & 3.48 & 1.403 & \\
\hline \multirow{2}{*}{$\begin{array}{l}\text { 1. I would not mind if someone } \\
\text { from my family attends same } \\
\text { classes with the child of the } \\
\text { asylum seeker. }\end{array}$} & Dugave & $9.3 \%$ & $8.7 \%$ & $12.7 \%$ & $24.0 \%$ & $45.3 \%$ & 150 & 3.87 & 1.328 & \multirow{2}{*}{.622} \\
\hline & Trnje & $4.1 \%$ & $1.4 \%$ & $10.2 \%$ & $23.1 \%$ & $61.2 \%$ & 147 & 4.36 & 1.006 & \\
\hline $\begin{array}{l}\text { 19. Asylum seekers should be } \\
\text { allowed to practice their own }\end{array}$ & Dugave & $11.5 \%$ & $10.8 \%$ & $20.3 \%$ & $24.3 \%$ & $33.1 \%$ & 148 & 3.57 & 1.351 & .491 \\
\hline
\end{tabular}




\begin{tabular}{|c|c|c|c|c|c|c|c|c|c|c|}
\hline $\begin{array}{l}\text { customs and tradition if they } \\
\text { want to. }\end{array}$ & Trnje & $6.7 \%$ & $6.0 \%$ & $18.8 \%$ & $21.5 \%$ & $47.0 \%$ & 149 & 3.96 & 1.230 & \\
\hline \multicolumn{11}{|c|}{ Factor $\mathbf{2}-$ Economy/health dimension (Cronbach's alpha of the composite scale $=0.662$ ) } \\
\hline \multirow{2}{*}{$\begin{array}{l}\text { 16. Asylum seekers do not } \\
\text { represent a burden for the } \\
\text { taxpayers. }\end{array}$} & Dugave & $35.3 \%$ & $23.3 \%$ & $22.7 \%$ & $10.7 \%$ & $8.0 \%$ & 150 & 2.33 & 1.277 & \multirow{2}{*}{.867} \\
\hline & Trnje & $24.5 \%$ & $25.9 \%$ & $28.6 \%$ & $10.2 \%$ & $10.9 \%$ & 147 & 2.57 & 1.266 & \\
\hline \multirow{2}{*}{$\begin{array}{l}\text { 2. Asylum seekers are not a } \\
\text { burden for the economic } \\
\text { development of our country. }\end{array}$} & Dugave & $32.0 \%$ & $16.7 \%$ & $28.7 \%$ & $8.7 \%$ & $14.0 \%$ & 150 & 2.56 & 1.383 & \multirow{2}{*}{.671} \\
\hline & Trnje & $12.1 \%$ & $17.4 \%$ & $27.5 \%$ & $22.1 \%$ & $20.8 \%$ & 149 & 3.22 & 1.294 & \\
\hline \multirow{2}{*}{$\begin{array}{l}\text { 4. Asylum seekers do not } \\
\text { represent a health threat to } \\
\text { our community. }\end{array}$} & Dugave & $19.3 \%$ & $13.3 \%$ & $34.0 \%$ & $20.0 \%$ & $13.3 \%$ & 150 & 2.95 & 1.284 & \multirow{2}{*}{.580} \\
\hline & Trnje & $9.5 \%$ & $12.2 \%$ & $20.9 \%$ & $28.4 \%$ & $29.1 \%$ & 148 & 3.55 & 1.285 & \\
\hline \multicolumn{11}{|c|}{ Factor 3 - Dimension of ethnocultural similarity (Cronbach's alpha of the composite scale $=0.662$ ) } \\
\hline \multirow{2}{*}{$\begin{array}{l}\text { 17. I would like asylum seekers } \\
\text { in Croatia to be similar to the } \\
\text { Croatian residents by their skin } \\
\text { colour. }\end{array}$} & Dugave & $40.7 \%$ & $19.3 \%$ & $24.0 \%$ & $6.7 \%$ & $9.3 \%$ & 150 & 2.25 & 1.305 & \multirow{2}{*}{.769} \\
\hline & Trnje & $53.4 \%$ & $13.5 \%$ & $17.6 \%$ & $8.8 \%$ & $6.8 \%$ & 148 & 2.02 & 1.296 & \\
\hline \multirow{2}{*}{$\begin{array}{l}\text { 12. I would like asylum seekers } \\
\text { in Croatia to be similar to the } \\
\text { Croatian residents by their } \\
\text { ethnic affiliation. }\end{array}$} & Dugave & $14.1 \%$ & $14.8 \%$ & $22.1 \%$ & $29.5 \%$ & $19.5 \%$ & 149 & 3.26 & 1.316 & \multirow{2}{*}{.757} \\
\hline & Trnje & $22.4 \%$ & $9.5 \%$ & $31.3 \%$ & $16.3 \%$ & $20.4 \%$ & 147 & 3.03 & 1.409 & \\
\hline \multirow{2}{*}{$\begin{array}{l}\text { 8. I would not like someone } \\
\text { from my family to marry an } \\
\text { asylum seeker. }\end{array}$} & Dugave & $10.0 \%$ & $14.0 \%$ & $24.0 \%$ & $18.0 \%$ & $34.0 \%$ & 150 & 3.52 & 1.350 & \multirow{2}{*}{.609} \\
\hline & Trnje & $29.7 \%$ & $14.2 \%$ & $20.9 \%$ & $15.5 \%$ & $19.6 \%$ & 148 & 2.81 & 1.500 & \\
\hline \multicolumn{11}{|c|}{ Factor 4 - Dimension of AS credibility estimation (Cronbach's alpha of the composite scale $=0.695$ ) } \\
\hline \multirow{2}{*}{$\begin{array}{l}\text { 10. Asylum seekers are } \\
\text { basically covert economic } \\
\text { migrants in pursuit of better } \\
\text { life. }\end{array}$} & Dugave & $4.7 \%$ & $8.0 \%$ & $26.0 \%$ & $33.3 \%$ & $28.0 \%$ & 150 & 3.72 & 1.100 & \multirow{2}{*}{.850} \\
\hline & Trnje & $11.5 \%$ & $17.6 \%$ & $31.1 \%$ & $18.9 \%$ & $20.9 \%$ & 148 & 3.20 & 1.278 & \\
\hline \multirow{2}{*}{$\begin{array}{l}25 . \text { People coming to Europe at } \\
\text { the moment are not real } \\
\text { refugees because they come in } \\
\text { pursuit of higher income and } \\
\text { better life. }\end{array}$} & Dugave & $4.7 \%$ & $10.0 \%$ & $34.0 \%$ & $20.7 \%$ & $30.7 \%$ & 150 & 3.63 & 1.156 & \multirow{2}{*}{.819} \\
\hline & Trnje & $12.8 \%$ & $15.4 \%$ & $28.2 \%$ & $19.5 \%$ & $24.2 \%$ & 149 & 3.27 & 1.329 & \\
\hline
\end{tabular}

\section{2) Descriptives - Attitudes based on locational attributes of AS reception}

\begin{tabular}{|c|c|c|c|c|c|c|c|c|c|c|}
\hline & & 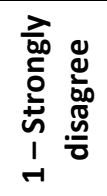 & $\begin{array}{l}\mathscr{d} \\
\frac{1}{00} \\
\frac{\mathscr{D}}{0} \\
\dot{0} \\
\dot{N}\end{array}$ & 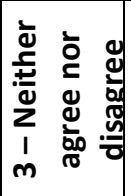 & 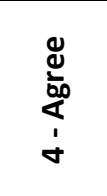 & 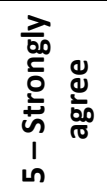 & $\mathbf{N}$ & M & SD & 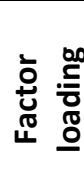 \\
\hline \multicolumn{11}{|c|}{ Factor 1 - Reception / residential preferences (Cronbach's alpha of the composite scale $=0.867$ ) } \\
\hline \multirow{2}{*}{$\begin{array}{l}\text { 4. I would not like to live on } \\
\text { the same street or } \\
\text { neighbourhood with asylum } \\
\text { seekers. }\end{array}$} & Dugave & $20.7 \%$ & $15.3 \%$ & $22.7 \%$ & $16.7 \%$ & $24.7 \%$ & 150 & 3.09 & 1.462 & \multirow[b]{2}{*}{-.705} \\
\hline & Trnje & $28.2 \%$ & $16.8 \%$ & $26.2 \%$ & $13.4 \%$ & $15.4 \%$ & 149 & 2.71 & 1.406 & \\
\hline \multirow{2}{*}{$\begin{array}{l}\text { 3. Shelter for asylum } \\
\text { Seekers does not cause decline } \\
\text { of real estate prices in the } \\
\text { immediate vicinity. }\end{array}$} & Dugave & $32.7 \%$ & $14.0 \%$ & $25.3 \%$ & $13.3 \%$ & $14.7 \%$ & 150 & 2.63 & 1.430 & \multirow[b]{2}{*}{.698} \\
\hline & Trnje & $21.5 \%$ & $22.8 \%$ & $31.5 \%$ & $14.1 \%$ & $10.1 \%$ & 149 & 2.68 & 1.242 & \\
\hline
\end{tabular}




\begin{tabular}{|c|c|c|c|c|c|c|c|c|c|c|}
\hline \multirow{2}{*}{$\begin{array}{l}\text { 2. I would not like to live in the } \\
\text { immediate vicinity of a shelter } \\
\text { for asylum seekers. }\end{array}$} & Dugave & $16.0 \%$ & $14.0 \%$ & $20.7 \%$ & $19.3 \%$ & $30.0 \%$ & 150 & 3.33 & 1.441 & \multirow{2}{*}{-.687.} \\
\hline & Trnje & $16.1 \%$ & $12.1 \%$ & $26.2 \%$ & $21.5 \%$ & $24.2 \%$ & 149 & 3.26 & 1.376 & \\
\hline \multirow{2}{*}{$\begin{array}{l}\text { 8. Shelter for asylum seekers } \\
\text { does not represent the brake } \\
\text { to the touristic development of } \\
\text { the area in which it is placed. }\end{array}$} & Dugave & $24.7 \%$ & $20.0 \%$ & $24.0 \%$ & $14.7 \%$ & $16.7 \%$ & 150 & 2.79 & 1.403 & \multirow[b]{2}{*}{.685} \\
\hline & Trnje & $18.1 \%$ & $14.8 \%$ & $33.6 \%$ & $12.8 \%$ & $20.8 \%$ & 149 & 3.03 & 1.358 & \\
\hline \multirow{2}{*}{$\begin{array}{l}\text { 10. I would buy a house or a } \\
\text { flat in the immediate vicinity of } \\
\text { the shelter for asylum seekers. }\end{array}$} & Dugave & $42.0 \%$ & $18.7 \%$ & $22.7 \%$ & $10.0 \%$ & $6.7 \%$ & 150 & 2.21 & 1.271 & \multirow{2}{*}{.675} \\
\hline & Trnje & $21.6 \%$ & $17.6 \%$ & $33.8 \%$ & $12.2 \%$ & $14.9 \%$ & 148 & 2.81 & 1.316 & \\
\hline \multirow{2}{*}{$\begin{array}{l}\text { 5. Shelter for asylum seekers } \\
\text { should be properly isolated } \\
\text { and remote from inhabited } \\
\text { areas. }\end{array}$} & Dugave & $24.0 \%$ & $9.3 \%$ & $22.7 \%$ & $19.3 \%$ & $24.7 \%$ & 150 & 3.11 & 1.495 & \multirow[b]{2}{*}{-.665} \\
\hline & Trnje & $28.4 \%$ & $23.6 \%$ & $18.9 \%$ & $12.8 \%$ & $16.2 \%$ & 148 & 2.65 & 1.428 & \\
\hline \multirow{2}{*}{$\begin{array}{l}\text { 7. I would not mind if an } \\
\text { asylum seeker was my next- } \\
\text { door neighbour. }\end{array}$} & Dugave & $25.3 \%$ & $16.0 \%$ & $24.0 \%$ & $13.3 \%$ & $21.3 \%$ & 150 & 2.89 & 1.471 & \multirow{2}{*}{.583} \\
\hline & Trnje & $8.8 \%$ & $14.3 \%$ & $25.9 \%$ & $16.3 \%$ & $34.7 \%$ & 147 & 3.54 & 1.331 & \\
\hline \multicolumn{10}{|l|}{ Factor 2 - Percept } & \\
\hline \multirow{2}{*}{$\begin{array}{l}\text { 16. Croatia should ensure } \\
\text { secure accommodation for } \\
\text { asylum seekers. }\end{array}$} & Dugave & $9.3 \%$ & $6.0 \%$ & $18.7 \%$ & $26.7 \%$ & $39.3 \%$ & 150 & 3.81 & 1.278 & \multirow{2}{*}{.790} \\
\hline & Trnje & $5.4 \%$ & $5.4 \%$ & $16.1 \%$ & $20.8 \%$ & $52.3 \%$ & 149 & 4.09 & 1.176 & \\
\hline \multirow{2}{*}{$\begin{array}{l}\text { 15. Empty objects owned by } \\
\text { the state should be used to } \\
\text { accommodate asylum seekers. }\end{array}$} & Dugave & $22.8 \%$ & $8.7 \%$ & $18.1 \%$ & $27.5 \%$ & $22.8 \%$ & 149 & 3.19 & 1.472 & \multirow[t]{2}{*}{.699} \\
\hline & Trnje & $12.8 \%$ & $8.7 \%$ & $22.8 \%$ & $25.5 \%$ & $30.2 \%$ & 149 & 3.52 & 1.344 & \\
\hline \multirow{2}{*}{$\begin{array}{l}\text { 9. Asylum seekers could } \\
\text { positively influence the } \\
\text { demographic development of } \\
\text { area they live in. }\end{array}$} & Dugave & $24.8 \%$ & $14.8 \%$ & $34.9 \%$ & $13.4 \%$ & $12.1 \%$ & 149 & 2.73 & 1.303 & \multirow[b]{2}{*}{.643} \\
\hline & Trnje & $11.4 \%$ & $9.4 \%$ & $26.2 \%$ & $26.8 \%$ & $26.2 \%$ & 149 & 3.47 & 1.287 & \\
\hline \multirow{2}{*}{$\begin{array}{l}\text { 13. Asylum seekers should not } \\
\text { access private accommodation } \\
\text { on the same conditions as } \\
\text { Croatian citizens. }\end{array}$} & Dugave & $26.0 \%$ & $14.7 \%$ & $26.0 \%$ & $12.7 \%$ & $20.7 \%$ & 150 & 2.87 & 1.462 & \multirow{2}{*}{-.591} \\
\hline & Trnje & $37.8 \%$ & $12.2 \%$ & $29.7 \%$ & $9.5 \%$ & $10.8 \%$ & 148 & 2.43 & 1.361 & \\
\hline \multirow{2}{*}{$\begin{array}{l}\text { 14. Shelter for asylum seekers } \\
\text { ensures adequate quality of } \\
\text { life. }\end{array}$} & Dugave & $5.4 \%$ & $8.8 \%$ & $36.1 \%$ & $21.1 \%$ & $28.6 \%$ & 147 & 3.59 & 1.152 & \multirow{2}{*}{-.493} \\
\hline & Trnje & $6.1 \%$ & $14.9 \%$ & $48.6 \%$ & $14.9 \%$ & $15.5 \%$ & 148 & 3.19 & 1.065 & \\
\hline
\end{tabular}

